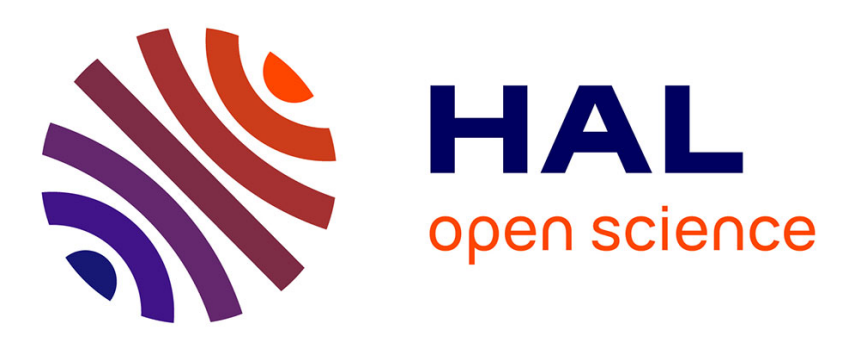

\title{
Browsing and non-browsing extant and extinct giraffids Evidence from dental microwear textural analysis
}

\author{
Gildas Merceron, Marc Colyn, Denis Geraads
}

\section{To cite this version:}

Gildas Merceron, Marc Colyn, Denis Geraads. Browsing and non-browsing extant and extinct giraffids Evidence from dental microwear textural analysis. Palaeogeography, Palaeoclimatology, Palaeoecology, 2018, 505, pp.128-139. 10.1016/j.palaeo.2018.05.036 . hal-01834854v2

\section{HAL Id: hal-01834854}

\section{https://hal-univ-rennes1.archives-ouvertes.fr/hal-01834854v2}

Submitted on 6 Sep 2018

HAL is a multi-disciplinary open access archive for the deposit and dissemination of scientific research documents, whether they are published or not. The documents may come from teaching and research institutions in France or abroad, or from public or private research centers.
L'archive ouverte pluridisciplinaire $\mathbf{H A L}$, est destinée au dépôt et à la diffusion de documents scientifiques de niveau recherche, publiés ou non, émanant des établissements d'enseignement et de recherche français ou étrangers, des laboratoires publics ou privés. 
1 Browsing and non-browsing extant and extinct giraffids: evidence from dental microwear

2 textural analysis.

3

4 Gildas MERCERON ${ }^{1}$, Marc COLYN $^{2}$, Denis GERAADS ${ }^{3}$

5

$6 \quad{ }^{1}$ Palevoprim (UMR 7262, CNRS \& Université de Poitiers, France)

$7{ }^{2}$ ECOBIO (UMR 6553, CNRS \& Université de Rennes 1, Station Biologique de Paimpont, 8 France)

$9 \quad{ }^{3}$ CR2P (UMR 7207, Sorbonne Universités, MNHN, CNRS, UPMC, France)

10

$11 \quad{ }^{1}$ Corresponding author: gildas.merceron@univ-poitiers.fr 
Abstract:

Today, the family Giraffidae is restricted to two genera endemic to the African continent, Okapia and Giraffa, but, with over ten genera and dozens of species, it was far more diverse in the Old World during the late Miocene. We attempt to describe here how several species may have shared feeding resources in the Eastern Mediterranean. Dietary preferences were explored by means of Dental Microwear Textural Analysis in combination with estimation of body mass and the maximum height at which the various species were able to browse.

One of our main results concerns the modern okapi, Okapia johnstoni. It is a forest dweller usually regarded as a browser, but we show that it might also forage on tough plants, possibly herbaceous monocots. Such feeding habits including portions of herbaceous monocotyledons were also found for some extinct species, especially the genera Samotherium and Palaeotragus. Palaeogiraffa shows a contrasted pattern: the specimens of $P$. pamiri from a site in Thrace were leaf-dominant browsers whereas those belonging to $P$. major and $P$. macedoniae from the Axios valley in Greece ingested herbaceous monocotyledons. Helladotherium duvernoyi, the only sivatheriine analyzed here is described as a leaf-dominant browser. The giraffine Bohlinia attica also falls within the leaf-dominant browser category but could browse on higher foliages than $H$. duvernoyi. On the whole, the reconstructed diets confirm the relationship between more grazing habits and smaller premolars, but not with higher dental crown height.

Keywords: Tooth, Ruminant, Neogene, Diet, Ecology 


\section{Introduction}

Today, giraffids are poorly diverse with only two genera, Okapia and Giraffa (Agaba et al., 2016), both endemic to the African continent. The okapi Okapia johnstoni is endemic to the north east of the Democratic Republic of Congo in the Congo Basin. There, the okapi is confined to dense equatorial forest, which explains why its anatomical description in a scientific journal dates back only to the early 20th century. Okapia johnstoni is unknown as a fossil, but its discovery has generated several hypotheses regarding its relationships with the giraffe and the many species of extinct giraffids (Colbert, 1938; Thenius, 1992). The modern giraffe has a wide range of distribution in subsaharan Africa. The genus dates back to the early Pliocene. A large part of the evolutionary history of the Giraffidae did not take place in Africa but in Eurasia during the Neogene (Solounias et al., 2010). With over 10 genera and dozens of named species that can be conveniently grouped in three subfamilies (Sivatheriinae, Giraffinae, Palaeotraginae), the family reached its highest diversity during the late Miocene. They share with modern taxa a small set of synapomorphies such as large body size, bilobate canine, and a molariform fourth premolar, but their skin-covered cranial appendages are not exclusive to the family (Geraads, 1986). A phylogenetic analysis of giraffids based upon new material from the late Miocene of Spain confirmed the monophylies of the two subfamilies Sivatheriinae and Giraffinae. However, the Sivatheriinae appear as the sister-group of the genus Samotherium and are thus rooted within the Palaeotraginae, whose paraphyletic status is thus emphasized (Ríos et al., 2017, 2016).

The present study aims at determining the feeding ecology of the extinct giraffids from the late Miocene of Eastern Mediterranean in regard to their differences in morphology mirroring the phylogeny. We use dental microwear textural analysis (DMTA, hereafter) to specify the dietary habits. First, we discuss the relations between dietary habits and dental microwear textural parameters on extant species of ruminants. This allows us to interpret and 
discuss the dental microwear textural parameters of species with unknown feeding habits. Before applying these parameters to extinct species of giraffids to identify their feeding type, we question the dietary habits of the present-day okapi, a species assumed to be a browser on the basis of a single field ecological survey (Hart and Hart, 1989). Second, we discuss the dietary reconstruction of these extinct species in relation to the morphology, and notably the body mass estimates and the length of the metacarpal bone, the latter feature being a proxy to assess the maximum height at which a given species can access the food resources. We may expect that smaller species with shorter forelimbs are more prone to include herbaceous vegetation than large species of giraffids. This permits us to evaluate the ecological niche partitioning when species co-occurred in the fossil record, suggesting an overlap of their home-range, such as at Pikermi (Greece) and Hadjidimovo (Bulgaria). Besides, considering that none of these giraffids displayed post canine hypsodont cheekteeth, we may expect that none of these giraffids included herbaceous vegetation in its diet. However, an early pioneer study on dental abrasion (Solounias et al., 1988) challenged the hypothesis of browsing habits among all extinct giraffids. These authors depicted Samotherium boissieri, a late Miocene giraffid from Samos Island (Greece) as a mixed feeding species incorporating silica-bearing herbaceous monocotyledons in its diet. Previous dental wear analysis on material from historical collections of Samos and Pikermi also found out differences between giraffids species (Danowitz et al., 2016; Solounias, 1988; Solounias et al., 2000). We here go further in significantly increasing the sample with new material from northern Greece, Bulgaria and Turkey.

\section{Material and Methods}

\subsection{Material}


The dental microwear textures of extinct giraffids are compared with those of present-

day species of ruminants with known differences in diet (housed in the following museum and institutions: AMNHS Aegean Museum of Natural Histry of Samos, Greece; NHMEU Natural History Museum of the Ege University of Izmir, Turkey; NHML Natural History Museum of London, UK; NHMB Naturhistorisches Museum Basel, Switzerland; SMNS Staatliches Museum für Naturkunde Stuttgart, Germany; SMNK Staatliches Museum für Naturkunde Karlsruhe, Germany; SNG Senckenberg Museum, Franckfort, Germany; UP Palevoprim lab, University of Poitiers, France; KNM National Museums of Kenya, Nairobi, Kenya; MNHN Muséum National dôHistoire Naturelle, Paris, France; MRAC Central African Royal Museum of Tervuren, Belgium; FSL Collection de Géologie de la Faculté des Sciences de l'Université de Lyon, France; AM-NHNMS Assenovgrad Museum; a division of the National Museum of Natural History of Sofia, Bulgaria). Instead of selecting a large dataset covering the whole spectrum of feeding habits, we chose here to focus on four taxa representing four different dietary poles (Table 1). These taxa are the hartebeest (Alcelaphus buselaphus, grazer; Estes, 1991; Gagnon and Chew, 2000), the red deer (Cervus elaphus, generalist; Gebert and Verheyden-Tixier, 2001), the giraffe (Giraffa sp., leaf-dominant browser; Estes, 1991; Leuthold, 1978; Parker et al., 2003) and the yellow-backed duiker (Cephalophus silvicultor; fruit-dominant browser; Estes, 1991; Gagnon and Chew, 2000; Gauthier-Hion et al., 1980; Lumpkin and Kranz, 1984). These ruminants share a common occlusal molar pattern. A fifth modern species is included in this study: Okapia johnstoni, the okapi, assumed to be a browser (Hart and Hart, 1989).

The taxonomy of the modern giraffe is currently under debate among zoologists. Several subspecies of Giraffa camelopardalis, differing in their horns and coat ornamentations had been identified (Brown et al., 2007; Groves and Grubb, 2011; Hassanin et al., 2007; Kingdon et al., 2013; Wilson and Reeder, 2005) but a recent study based on multi- 
locus DNA analysis recognizes the existence of four species (Fennessy et al., 2016): $G$. giraffa (southern giraffe), G. tippelskirchi (Masai giraffe), G. reticulata (reticulated giraffe) and G. camelopardalis (northern giraffe). The geographical distribution of the giraffe and its genetic diversity were even higher until the Holocene since subfossil remains and glyph representations in caves and rock shelters attest to its presence 4,000 years ago in northwestern Africa and along the Nile Valley (Le Quellec, 1999). Because of these taxonomic uncertainties, we made the choice to group all modern giraffes under Giraffa sp. Our purpose here is to have an ecologically homogeneous milestone to represent the leaf-dominant browsing ecospace. None of the specimens of modern species used in this study were captive before death, they were shot in the wild decades ago.

The fossil specimens belong to six genera: Bohlinia, Helladotherium, Palaeogiraffa, Palaeotragus and Samotherium. The material comes from a dozen upper Miocene (Vallesian and Turolian) localities in Greece, Bulgaria, Turkey, Afghanistan, Iran and Tunisia (Table 1, Fig. 1). Helladotherium duvernoyi comes from the turolian faunas of Southern Bulgaria (Geraads et al., 2005; Spassov, 2002), continental Greece (Kostopoulos et al., 1996; Solounias, 1981), and southern Tunisia (but the identification there is less secure). The specimens attributed to Bohlinia attica (Giraffinae) come from Nikiti-1 in Greece dated to close to the Vallesian-Turolian transition (Kostopoulos, 2016) and from Kalimantsi (K), Bulgaria (Geraads et al., 2005). Among the Palaeotraginae, the specimens assigned to Samotherium major come from turolian sites: Mytilini-A, Mytilini-B (MTLA and MTLB; two sites from the Mytilini ravines in Samos Island, Greece; Kostopoulos, 2009), Vathylakkos-3 (VAT) in the Axios Valley (Geraads, 1978), Salihpasalar (MYS) and k̦erefköy-1 (MYSe-1) in the Muĵ la Yatâjan Basin of Turkey (Kaya et al., 2012), and from the Turolian of Mahmutgazi (MA) in Turkey (Sickenberg, 1975). The specimens of S. boissieri do not come from recent excavations but belong to historical collections from Samos for which site 
provenance is not guaranteed (see Koufos, 2009 for a historical review of the paleontological surveys and studies in Samos). A single specimen attributed to Samotherium neumayri comes from Maragha (MAR), Iran (Solounias and Danowitz, 2016, as Alcicephalus neumayri). The genus Palaeotragus is represented by two taxa. A single specimen of Palaeotragus rouenii from the vallesian site of Ravin de la Pluie (RPI; Geraads, 1978; Koufos, 2006) has been analyzed but the species is widespread and abundant in the turolian sites of Hadjidimovo (HD; Geraads et al., 2005), Dytiko-3 (DIT), Pikermi (PIK; Koufos, 2006), Mytilini-B (MTLB; Kostopoulos, 2009), k̦erefköy-1 and k̦erefköy-2 (MYSe-1 and MYSe-2; Kaya et al., 2012) and Molayan (MOL; Afghanistan; Brunet and Heintz, 1983; Sen, 1998). Specimens that belong to Palaeotragus coelophrys or to a closely related species come from the vallesian sites of Ravin de la Pluie (RPl) and Pentalophos (PNT) in Greece (Koufos, 2006) and from Maragha (MAR) in Iran (Mecquenem, 1924; Solounias and Danowitz, 2016). Palaeogiraffa pamiri comes from the vallesian sites of Küçükçekmece (KUC) in Turkish Thrace (Kostopoulos and Sen, 2016). The only specimen of Palaeogiraffa major comes from the vallesian site of Ravin de la Pluie (Koufos, 2006). A third species of Palaeogiraffa, P. macedoniae is known from the vallesian site of Pentalophos (PNT), also in the Axios Valley (Koufos, 2006). Ríos et al. (2016, 2017) synonymized Palaeogiraffa and Decennatherium (a genus assumed to be the sister group of a clade composed notably by sivatherines and Samotherium major and S. boissieri), a view which is not shared by Bonis \& Bouvrain (2003). Pending agreement on this taxonomic issue, we keep using Palaeogiraffa as genus name for specimens from the vallesian sites from Axios, in northern Greece and from Yulaflē in Turkish Thrace.

For some of the species, the number of specimens is large enough $(\mathrm{N}=>10)$ to generate robust interpretations regarding their dietary habits. However, for several taxa, the number is moderate $(5=<\mathrm{N}<10)$ and even low $(5<\mathrm{N})$. Taking into account that dental microwear textures 
reflect the dietary bolus from the last few weeks, one might fear that the signal from such small samples is meaningless, but Purnell et al. (2012) have shown that significant differences in textural parameters can be detected even for small samples $(\mathrm{N}<5)$ of fishes (see also Purnell et al., 2013). Besides, the analysis of several scans per individual, as proposed by Purnell and Darras (2016) and as done in the present study, mitigates the effects of the small sample size..

\subsection{Methods}

DMTA is a method quantifying tooth abrasion (for detailed reviews of intra- and interobserver errors, see DeSantis et al., 2013; Galbany et al., 2005; Grine et al., 2002; Mihlbachler et al., 2012; Calandra and Merceron, 2016; Mihlbachler and Beatty, 2012; Scott, 2012; Scott et al., 2006) . Tooth wear reflects individual senescence and physical properties of foods; thus, it is correlated with the availabilities of food resources and can be used to explore niche partitioning among sympatric species of mammals (Calandra and Merceron, 2016). From the scale of a whole tooth to the micrometric scars on dental facets, differences in dietary preferences are mirrored by tooth wear. DMTA has proved to be a particularly useful methodology free of (inter- and intra-)observer measurement errors at least at the analytic step (for detailed reviews of intra- and inter-observer errors, see DeSantis et al., 2013; Galbany et al., 2005; Grine et al., 2002; Mihlbachler et al., 2012; Mihlbachler and Beatty, 2012) in assessing diets of fossil as well as modern taxa (Calandra and Merceron, 2016).

The analysis was performed preferentially on second upper or lower molars (Figs. 2 and 3). However, third or first molars were considered when the second molars are weathered, too much worn or too recently erupted. Following standard procedures, replicas of dental facet were produced with a silicone (medium consistency) polyvinylsiloxane (Coltène Whaledent, President Regular Body, ISO 4823). Scans (320 x $280 \mu \mathrm{m})$ were produced on 
replicas using a surface profilometer confocal DCM8 Leica Microsystems with a 100× lens (Leica Microsystems; NA $=0.90$; working distance $=0.9 \mathrm{~mm}$ ) at the Palevoprim, CNRS and University of Poitiers, France. Lateral resolution is $0.129 \mu \mathrm{m}$ and vertical spacing is 0.002 $\mu \mathrm{m}$. Up to four surfaces $(140 \times 100 \mu \mathrm{m} ; 1088 \times 776$ pixels $)$ were generated from the original scans and saved as .Pl $\mu$ files (Figs. 2 and 3; details on surface preparation are given in Merceron et al. 2016).

The DMTA was performed using the Scale-Sensitive Fractal Analysis using Toothfrax and Sfrax software (Surfract, http://www.surfract.com) following Scott et al. (2006). The individual values of surface parameters for extinct and extant species are given in Appendix 1. Three variables were extracted from the surface: complexity (Asfc), anisotropy (epLsar), and heterogeneity of complexity (HAsfc calculated with a 9-cell mesh; Table 1). Scott et al. (2006) detailed the variables used here. Complexity (Asfc or Area-scale fractal complexity) is a measure of the roughness at a given scale. Anisotropy (epLsar or exact proportion of lengthscale anisotropy of relief) measures the orientation concentration of surface roughness. Heterogeneity of complexity (HAsfc or heterogeneity of area-scale fractal complexity), quantifies the variation of complexity within scan. All of these three textural parameters are dimensionless (see Scott et al., 2006). Scanned surfaces display dental microwear but also, for some of the teeth, structural reliefs such as growth lines or perikemata reflecting the intersection between Retzius lines with the enamel surface. One may argue that such enamel structural relief influences the parameter values, and notably the anisotropy of the dental microwear textures. Although the perikemata are more or less preferentially orientated, they do not interfere with the anisotropy calculation, because the height amplitudes of these perikemata are lower than topographic variations due to the microwear on enamel surfaces (Fig. 4). 
As the distribution of textural parameters violates conditions for parametric tests,

variables were rank-transformed before analysis (Conover and Iman, 1981; Sokal and Rohlf, 1969). One-way factorial ANOVAs with post-hoc tests for each parameter were used to determine the sources of significant variation (Tables 2 and 3). Any potential difference was then highlighted using the combination of the conservative HSD test (Tukeyô Honest Significant Differences) together with the less conservative LSD test (Fisherô Least Significant Differences).

Body mass (calculated according Scott, 1990) and height at the withers are two body traits that can be used in combination with DMTA to explore the partitioning of food resources between sympatric species. Here we use metacarpal length as a proxy of height at the withers and the height at which a species can gather its resources. This certainly suffers exceptions, but the length of the metacarpals is a good proxy for the height at which the animal can browse (for a given metacarpal length, if the animal is heavier, height at the withers will be higher, but neck will be shorter). We also noted classic parameters of dental morphology, notably the premolar/molar ratio that is distinctly lower for hyper-grazing bovids (Table 4).

\section{Results and Discussion}

\subsection{Dental microwear textures and diet}

The four modern species used as milestones differ from each other in all three surface textural parameters (Tables 1-3). The hartebeest (Alcelaphus buselaphus), a grazing alcelaphine, has the lowest enamel surface complexity (Asfc) and the highest anisotropy (epLsar) of dental microwear textures (Tables 1 and 3; Figs. 2 and 4). The yellow-backed duiker (Cephalophus silvicultor) displays the highest complexity (Asfc) and low values of anisotropy (epLsar) whereas the giraffe (Giraffa sp.) has the lowest anisotropy (epLsar) and 
an intermediate complexity (Asfc) between the hartebeest and the yellow-backed duiker (Tables 1 and 3; Figs. 2 and 5). The differences in dental microwear textures between the two browsing species reflect the ingestion of fruits and seeds by the duiker (Ramdarshan et al., 2016). The dental microwear textures (intermediate complexity and anisotropy) of the red deer (Cervus elaphus) reflect its mixed feeding habits that involve both browsing and grazing (Tables 1 and 3; Figs. 2 and 5). The third variable, heterogeneity of complexity (HAsfc), provides a significant complement. The giraffe and the hartebeest foraging mostly on a homogeneous source of vegetation (tree leaves and herbaceous monocotyledons, respectively; Estes, 1991, Gagnon and Chew, 2000; Leuthold, 1978; Parker et al., 2003) over long time span (over a year) have lower values than the red deer and the yellow-backed duiker whose diets are mechanically diverse and variable from a day to another or from a season to another (Tables 1 and 3; Figs. 2 and 5; Estes, 1991; Gebert and Verheyden-Tixier, 2001; Gagnon and Chew, 2000; Gauthier-Hion et al. 1980; Lumpkin and Kranz, 1984).

The modern okapi (Okapia johnstoni) has a wide distribution across the dental microwear textural ecospace. It differs from the giraffe in having higher anisotropy (epLsar) and from the yellow-backed duiker in having lower complexity (Asfc; Tables 1 and 3; Figs. 3 and 5). The okapi also differs from the hartebeest and the giraffe in having higher heterogeneity of complexity (HAsfc). It does not differ from the red deer when the two most discriminating variables (Asfc and epLsar) are considered (Tables 1 and 3; Figs. 3 and 5). These results for the present-day okapi assumed to be a browser can be discussed in light of the ecological data. Hitherto, only one single study dealt with the feeding ecology of the okapi in the wild (Hart and Hart, 1989). It was conducted at Epulu, Ituri forest, a lowland forest located at the far north eastern of the Congo basin. The authors tracked eight collared individuals for several months and recorded from direct observations browse signs on vegetation but only those ranging from 0.5 to 2.0 meters in height because $\tilde{\text { r }}$ his is the forest 
layer most frequently browsed by okapiò (Hart and Hart, 1989: 35). There is indeed no record regarding lower vegetal layers. Hart and Hart (1989) identified shade- and light-tolerant plant species, all of them being dicotyledonous trees or bushes, constituting the staple food spectrum of the okapi. However, one of these two authors from the pioneer study mentions in Kingdon et al. (2013: in vol. VI, p. 110-115) that herbaceous monocotyledons are part of the okapi diet but does not provide details regarding their abundance. Hart and Hart (1989) had actually made mention that the okapi favors tree-fall gaps where it leaves the highest density of browse signs. These tree-fall gaps are also hotspots of biodiversity in the Central African forest where the herbaceous vegetation (mostly monocotyledons) reaches its highest diversity and density. These plant resources are known to be critical in dense forested habitats for other mammals such as buffaloes (Blake, 2002), gorillas, and pygmy chimpanzees (Blake et al., 1995; Malenky and Wrangham, 1994; Williamson et al., 1990). For instance, these apes feed on herbaceous stems (sometimes only the soft inner pith) of monocotyledonous plants such as Marantacea and Zingiberacea (Malenky and Wrangham, 1994; Williamson et al., 1990; Wrangham et al., 1991). Monocotyledonous plants have generally higher silica content than dicotyledonous plants (Hodson et al., 2005). Besides, the herbaceous stems that are eaten are tougher than most fruits(Elgart-Berry, 2004). Therefore, on the basis of the dental microwear textures of the okapis analyzed in the present study and the information provided by Hart and Hart (1989) and Hart in Kingdon et al. (2013), we hypothesize that the okapi does include some terrestrial herbaceous vegetation in its diet, especially when its home range overlaps tree fall gaps. Our hypothesis needs to be tested in the future through alternative direct or non direct dietary proxies and new material. It is worth mentioning that Clauss et al. (2006) had described the digestive tract of two captive okapis as similar to that of modern selective browsers with the exception that the parotid glands were found to be small, a feature shared with ruminants feeding on monocotyledons. 
All fossil giraffids but Samotherium boissieri (and the only specimen of Palaeogiraffa major, see Table 1) significantly differ from the grazing hartebeest in having either higher complexity (Asfc) or lower anisotropy (epLsar) or the combination of the two conditions (Tables 2 and 3; individual values are provided in table $\mathrm{S} 1$ in supplementary material). Like the modern giraffe, Helladotherium duvernoyi has lower anisotropy (epLsar) than the red deer and the hartebeest, and lower complexity (Asfc) than the yellow-backed duiker; it also has lower values in heterogeneity of complexity (HAsfc) than the red deer and the duiker, supporting a monotypic diet for this sivatheriine (Tables 1 and 3; Figs. 3 and 5; table S1). There is little doubt that Helladotherium $(\mathrm{N}=15)$ was a leaf-dominant browser. The five specimens of Bohlinia attica all have low values of both anisotropy (epLsar) and complexity (Asfc) suggesting that these individuals fed on soft browse (Tables 1 and 3; Figs. 3 and 5; table S1). The specimens of Palaeogiraffa pamiri from Turkish Thrace show low values in all three textural parameters (Tables 1 and 3; Figs. 3 and 5; table S1), showing that they were undoubtedly leaf-dominated browsers. By contrast, Palaeogiraffa macedoniae and the specimen of P. major from the Axios Valley sites in northern Greece display a sharply different pattern (Tables 1 and 3; Fig. 3; table S1). They have higher anisotropy (epLsar) than the sample from Thrace, the modern giraffe and the yellow-backed duiker. When complexity (Asfc) is also considered, such dental microwear textures suggest mixed feeding habits for Palaeogiraffa from the lower Axios Valley (Tables 1 and 3; Fig. 5; table S1). One may argue that differences in windblown dust deposit on vegetation could be the key factor controlling differences in dental microwear textures. However the only study that actually tested these hypotheses on living captive domesticated animals concludes that differences in (dust-free) diet generates significant differences in dental microwear textures (Merceron et al., 2016). Moreover, the effects on foods of dust simulating the Western Africa Harmattan windblown dust are not significant enough to hide the dietary signal (Merceron et al., 2016). Samotherium 
also displays a wide range of values (Tables 1 and 3; Figs. 3 and 5; table S1). Samotherium major differs from the modern giraffe in having higher anisotropy (epLsar), from the hartebeest in having a higher complexity (Asfc) and from the red deer, the yellow-backed duiker, and the okapi in its lower heterogeneity of complexity (HAsfc; Tables 1 and 3; Figs. 3 and 5; table S1). Samotherium boissieri also has higher anisotropy (epLsar) than the giraffe and the yellow-backed duiker. It is worth noting that there is no significant difference between S. boissieri and the grazing and mixed feeding species. The sample of Palaeotragus rouenii displays higher anisotropy (epLsar) than the modern giraffe and lower complexity (Asfc) than the yellow-backed duiker. This species covers the whole spectrum. cf. P. coelophrys shares the same pattern. On the whole, mixed feeding habits seem to be prevalent for all palaeotragines.

\subsection{Morphology, diet, and niche partitioning}

Modern giraffids constitute a relic of a diverse group that became impoverished during Pliocene and Pleistocene times, but during the late Miocene, their species and ecomorphological diversities were far greater than today. Body mass and heights at which they could gather food resources differed from one species to another (Table 4, Fig. 6). Helladotherium duvernoyi was likely the heaviest giraffe in Europe, weighting perhaps as much as two tons, whereas Palaeotragus rouenii was not larger than the modern okapi, at about $500 \mathrm{~kg}$. The length of their metacarpals, approximating height at the withers, and the height at which each species could reach its food, covered the whole range of the modern forms, from the okapi to the giraffe. The relative proportions of the premolar / molar rows are not very variable in the Giraffidae, which suggests that there were probably no huge differences in diets. On the basis of the index (Table 4, Fig. 6), and given low sample size, most fossil giraffes do not significantly differ from their modern relatives, except the 
paleotragines that have smaller premolars. This is in agreement with the dental microwear textural analysis that suggests more versatile feeding habits for paleotragines than other extinct giraffids.

Bohlinia attica was a giraffine weighting about a ton; it was likely able to reach foliage as high as the modern giraffe, from 4 to $6 \mathrm{~m}$ above ground (Table 4, Fig. 6; Leuthold, 1978; OâConnor et al., 2015). The dental microwear textures attest that B. attica fed mostly on soft foliages, as modern giraffes do (Figs. 5 and 6). The body traits found in Bohlinia and Giraffa and their similarities in tooth wear both suggest that the ecological niche of leafdominated browsers targeting the highest tree foliages was shared by the common ancestor. Among large giraffids, the sivatheriine Helladotherium duvernoyi weighted as much as two tons; the low values for the three textural parameters depict it as a likely leaf-dominant browser (Fig. 5). Thus, H. duvernoyi shared similar feeding habits with B. attica, in spite of its distinctly higher molar crowns (Table 4), but could not reach foliages as high as this species, which was less stoutly built, but taller (Table 4, Fig. 6). Palaeogiraffa is represented in this study by three species. They were less tall than $B$. attica, and thus had reduced competition with it to exploit tree foliages (Fig. 6). Palaeogiraffa pamiri from Thrace was likely a leaf-dominant browser while the contemporaneous $P$. macedoniae and $P$. major from the lower Axios valley in Greece may have incorporated herbaceous monocotyledons in their diet. Such contrasted differences between species of the same genus (Figs. 5 and 6) might reflect differences in food resources between the two regions (woody landscapes in the Thracian site and floodplain grasslands along the Axios).

In the late Miocene of the Mediterranean region, palaeotragines were more diverse than sivatheriines and giraffines, but the height range at which they could browse is far smaller than their species diversity and body mass range suggest. The palaeotragine Samotherium major has a body mass similar to that of the sivatheriine $H$. duvernoyi (Table 4, 
Fig. 6). These two species could reach the same foliage heights. Based on tooth morphology, we would have expected more grazing habits for the large palaeotragine compared to the sivatheriine, because small premolars compared to molars are usually taken as indicating more grazing habits in ruminants (Solounias and Dawson-Saunders, 1988), but no significant difference in the present study seems to distinguish the species with the larger premolars $(H$. duvernoyi) from the similar-sized species with the smaller premolars ( $S$. major; Table 4, Figs. 5 and 6). However, using dental microwear analysis on a larger sample, Solounias et al. (2010) regarded S. major as a mixed feeder. Based on a dental mesowear scoring approach, Danowitz et al. (2016) depicted it as a browser or a mixed feeder. To sum up, although the present study fails to discriminate $S$. major from $H$. duvernoyi, previous studies supported the view that $S$. major included herbaceous monocotyledons in its diet, as suggested by its dental morphology.

Samotherium boissieri differs from S. major in its lighter body mass and in being less tall at the withers. Besides, the slight differences in the morphology of the premaxilla (but not in the teeth) between these co-generic species (Fig. 7) suggest that S. boissieri might have ingested more herbaceous monocotyledons than $S$. major, although according to our own observation, the specimen NHMUK M 4215 has a distinctly less squarish premaxilla than typical grazers. Although our study fails to detect any significant differences between these two species of Samotherium, it is worth mentioning that, in contrast to S. major, S. boissieri has significantly higher values of anisotropy than modern browsing species (yellow-backed duiker and giraffe) and the three most presumably leaf browsing extinct giraffids (B. attica, $H$. duvernoyi, P. pamiri; Table 4, Figs. 5 and 6). Solounias et al. (1988) had also shown that $S$. boissieri includes herbaceous monocotyledons in its diet.

The genus Palaeotragus is represented by two species. Palaeotragus rouenii has a body mass similar to that of the modern okapi but could reach vegetal layers as high as those 
that H. duvernoyi and Samotherium spp. browsed (Table 4, Fig. 6). A more versatile diet than that of $H$. duvernoyi could explain their coexistence at some sites, and thus the probable overlap of their home ranges. Palaeotragus coelophrys was stouter than P. rouenii, but based on their metacarpal lengths, they could reach the same foliages. A fifth species of palaeotragine, Samotherium neumayri, is represented by a single individual whose body mass was similar to that of the modern giraffe but with a height at the withers similar to that of other palaeotragines; its dental microwear texture suggests that this specimen fed on soft foliages the few weeks before its death.

\subsection{Dietary adaptation and Phylogeny}

A recent study based on new material challenges the phylogeny of the giraffids (Ríos et al., 2017). Giraffines are represented by the modern giraffes and the species of the genus Bohlinia. The elongation of the cervical vertebrae and the extreme elongation of the metacarpal allowing them to forage on the highest arboreal stratum may be seen as an autapomorphy of the Giraffinae (Ríos et al., 2017). Our data strongly support such dietary adaptations. Besides, the monophyly of the paleotragines is challenged. According to their study, the genus Samotherium, previously thought to be close to Palaeotragus, actually shares a set of derived features with the Sivatherinae. The species of the genus Palaeotragus compose the sister group of a monophyletic group including the modern okapi,

Decennatherium, Palaeogiraffa (assumed to be close to the former genus according to these authors) and Samotherium in which the sivatherines (including Helladotherium) are rooted. More versatile feeding habits might have been the ancestral conditions for this second clade. In view of this phylogeny proposed by Ríos et al. (2017), we may consider that either browsing or mixed feeding habits were the ancestral ecological conditions for giraffids. The adaptation to leaf browsing occurred twice, first among Giraffines and then at least in 
411 show a shortening of the forelimbs in the course of the Pliocene, a morphological trend

412 correlated with the incorporation of a greater amount of $\mathrm{C}_{4}$ plants, i.e. herbaceous monocots, 413 in their diet. 


\section{Conclusions}

The present study explores the ecological diversity of the diverse radiation of giraffids

that took place during the late Miocene of the Eastern Mediterranean. In combination with body traits such as wither heights, and thus estimation of the height at which these extinct ruminants may have foraged, DMTA detects differences in feeding preferences. As expected, several of these extinct giraffids were leaf-dominant browsers but foraging at different heights. The modern giraffe can be consider as an appropriate model for understanding the ecology of Bohlinia. Helladotherium duvernoyi browsed at lower heights. Our study supports previous views that regarded the species of Samotherium as engaged in both browsing and grazing. Palaeogiraffa from the Axios valley in Greece undoubtedly included high amounts of tough plants, most likely tall herbaceous monocots, in its diet. The present study enlarges our knowledge of the ecology of this diversified group and emphasizes the importance of considering megaherbivores to faithfully depict past ecosystems and available resources. Indeed, together with proboscideans, rhinocerotids and chalicotheriids, giraffids compose a guild of megaherbivores with no analog in the modern ecosystems.

In addition, the present study provides surprising results regarding the okapi. Its dental microwear textures significantly differ from those of the leaf-eating giraffes as well as from those of the fruit-eating yellow-backed duikers. They show similarities with those of the red deer, a species eating both monocots and dicots. Here, we hypothesize that the okapi is not a browser sensu stricto. This giraffid feeds on a wider dietary spectrum than previously thought and likely forages on tough plants, possibly tall herbaceous monocotyledons when exploiting resources in tree fall gaps. 


\section{Acknowledgments}

The authors thank C. Sagne and P. Tassy (Muséum National d'Histoire Naturelle, Paris, France), E. Robert (Geological Collections, UMR CNRS 5276 Laboratoire de Géologie de Lyon - CERESE, University Lyon 1), N. Spassov and the late D. Kovatchev (National Museum of Natural History, Sofia, Bulgaria), D.S. Kostopoulos and G.D. Koufos (Aristotle University of Thessaloniki, Greece), S. Mayda and T. Kaya (Natural History Museum, Ege University, Izmir, Turkey), W. Wendelen (RMCA, Tervuren, Belgium), L. Costeur (Naturhistorisches Museum at Basel, Swizterland), and W. Munk (Staatliches Museum für Naturkunde, Karlsruhe, Germany), for giving access to collections. We are grateful to A. Souron (University of Bordeaux-1) who contributed to the sampling of okapis. A significant part of the fossil material was sampled in various European institutions thanks to the International Research Collaborative Grant "Environmental Dynamics of Western Eurasian Hominids during the Late Miocene" (PIs: R. S. Scott and T. Kaya) funded by the Wenner-Gren Foundation. G.M. thanks his colleagues of the ówenner-Gren International Research Collaborative Grantô̂group: R.S. Scott (Rutgers University, USA), D.S. Kostopoulos (Aristotle University of Thessaloniki, Greece), T. Kaya and S. Mayda (Ege University, Izmir, Turkey) as well as G. Reynaud and S. Riffaut (Palevoprim). We also thanks the associate editor I. Montanez and four reviewers including N. Spassov for their helpful comments that greatly improve the manuscript. This study was funded by the Project TRIDENT (ANR-13-JSV7-0008-01, PI: G. Merceron, France; http://anr-trident.prd.fr/).

\section{Data availability}

The dental microwear texture parameters for each fossil specimen are given in Appendix 1. 


\section{References}

462

463

464

465

466

467

468

469

470

471

472

473

474

475

476

477

478

479

480

481

482

483

484

Blake, S., 2002. Forest buffalo prefer clearings to closed-canopy forest in the primary forest of northern Congo. Oryx 36, 81 ï 86.

Blake, S., Rogers, E., Fay, J.M., Ngangoué, M., Ebéké, G., 1995. Swamp gorillas in northern Congo. Afr. J. Ecol. 33, 285ï 290. https://doi.org/10.1111/j.1365-2028.1995.tb00809.x

Bonis, L. de, Bouvrain, G., 2003. Nouveaux Giraffidae du Miocène supérieur de Macédoine (Grèce). Adv. Vertebr. Paleontol. ñHen Panta 5ï 16.

Brown, D.M., Brenneman, R.A., Koepfli, K.-P., Pollinger, J.P., Milá, B., Georgiadis, N.J., Louis, E.E., Grether, G.F., Jacobs, D.K., Wayne, R.K., 2007. Extensive population genetic structure in the giraffe. BMC Biol. 5, 1.

Brunet, M., Heintz, E., 1983. Interprétation paléoécologique et relations biogéographiques de la faune de vertébrés du Miocène supérieur dđ̂njana, Irak. Palaeogeogr. Palaeoclimatol. Palaeoecol. 44, $283 \ddot{1} 293$.

Calandra, I., Merceron, G., 2016. Dental microwear texture analysis in mammalian ecology: DMTA in ecology. Mammal Rev. 46, 215ï 228. https://doi.org/10.1111/mam.12063

Clauss, M., Hummel, J., Völlm, J., Lorenz, A., Hofmann, R.R., 2006. The allocation of a ruminant feeding type to the okapi (Okapia johnstoni) on the basis of morphological parameters. Zoo Anim. Nutr. 3, 253 ï 270.

Colbert, E.H., 1938. The relationships of the okapi. J. Mammal. 19, 47 ï 64.

Conover, W.J., Iman, R.L., 1981. Rank transformations as a bridge between parametric and nonparametric statistics. Am. Stat. 35, 12410129.

Danowitz, M., Hou, S., Mihlbachler, M., Hastings, V., Solounias, N., 2016. A combinedmesowear analysis of late Miocene giraffids from North Chinese and Greek localities of the Pikermian Biome. Palaeogeogr. Palaeoclimatol. Palaeoecol. 449, 194ї 204. 
DeSantis, L.R.G., Scott, J.R., Schubert, B.W., Donohue, S.L., McCray, B.M., Van Stolk, C.A., Winburn, A.A., Greshko, M.A., Ođ̃Hara, M.C., 2013. Direct Comparisons of 2D and 3D Dental Microwear Proxies in Extant Herbivorous and Carnivorous Mammals. PLoS ONE 8, e71428. https://doi.org/10.1371/journal.pone.0071428

Elgart-Berry, A., 2004. Fracture toughness of mountain gorilla (Gorilla gorilla beringei) food plants. Am. J. Primatol. 62, 275ï 285. https://doi.org/10.1002/ajp.20021

Estes, R.D., 1991. Behavior Guide to African mammals. The University of California Press, Los Angeles.

Fennessy, J., Bidon, T., Reuss, F., Kumar, V., Elkan, P., Nilsson, M.A., Vamberger, M., Fritz, U., Janke, A., 2016. Multi-locus Analyses Reveal Four Giraffe Species Instead of One. Curr. Biol. https://doi.org/10.1016/j.cub.2016.07.036

Gagnon, M., Chew, A.E., 2000. Dietary preferences in extant African Bovidae. J. Mammal. 8, $490 і ̈ 511$.

Galbany, J., Martínez, L.M., López-Amor, H.M., Espurz, V., Hiraldo, O., Romero, A., de Juan, J., Pérez-Pérez, A., 2005. Error rates in buccal-dental microwear quantification using scanning electron microscopy. Scanning 27, 23ї 29. https://doi.org/10.1002/sca.4950270105

Gauthier-Hion, A., Emmons, L.H., Dubost, G., 1980. A comparison of the diets of three major groups of primary consumers of Gabon (Primates, Squirrels and Ruminants). Oecologia 45, 18218189.

Gebert, C., Verheyden-Tixier, H., 2001. Variations of diet composition of red deer (Cervus elaphus L.) in Europe. Mammal Rev. 31, 189101201.

Geraads, D., 1989. Vertébrés fossiles du Miocène supérieur du Djebel Krechem El Artsouma (Tunisie centrale). Comparaisons biostratigraphiques. Géobios 22, 777ї 801.

Geraads, D., 1986. Remarques sur la systématique et la phylogénie des Giraffidae (Artiodactyla, Mammalia). Geobios 19, $465 і ̈ 477$. 
Geraads, D., 1978. Les Paleotraginae (Giraffidae, Mammalia) du Miocène supérieur de la

511 région de Thessalonique (Grèce). Géologie Mediterranéenne V, 269 Ï 276.

512

Geraads, D., Spassov, N., Kovachev, D., 2005. Giraffidae (Artiodactyla, Mammalia) from the

513

Late Miocene of Kalimantsi and Hadjidimovo, Southwestern Bulgaria. Geol. Balc. 35, 11 ï 18.

514

515

516

517

518

Grine, F.E., Ungar, P.S., Teaford, M.F., 2002. Error rates in dental microwear quantification using scanning electron microscopy. Scanning 24, $144 і ̈ 153$.

https://doi.org/10.1002/sca.4950240307

Groves, C., Grubb, P., 2011. Ungulate taxonomy. JHU Press.

Hart, J.A., Hart, T.B., 1989. Ranging and feeding behaviour of okapi (Okapia johnstoni) in the Ituri Forest of Zaire: food limitation in a rain-forest herbivore, in: Symposium of the Zoological Society of London. pp. 31 ï 50.

Hassanin, A., Ropiquet, A., Gourmand, A.-L., Chardonnet, B., Rigoulet, J., 2007. Mitochondrial DNA variability in Giraffa camelopardalis: consequences for taxonomy, phylogeography and conservation of giraffes in West and central Africa. C. R. Biol. 330, 265 Ï 274.

Hodson, M.J., White, P.J., Mead, A., Broadley, M.R., 2005. Phylogenetic variation in the silicon composition of plants. Ann. Bot. 96, 102710 1046.

Kaya, T.T., Mayda, S., Kostopoulos, D.S., Alcicek, M.C., Merceron, G., Tan, A., Karakutuk, S., Giesler, A.K., Scott, R.S., 2012. k̦erefköy-2, a new late Miocene mammal locality from the Yatẩ an Formation, Mụ̂ la, SW Turkey. Comptes Rendus Palevol 11, 5 ï 12.

Kingdon, J., Happold, D., Butynski, T., Hoffmann, M., Happold, M., Kalina, J., 2013. Mammals of Africa. A\&amp;C Black.

Kostopoulos, D.S., 2016. Palaeontology of the upper Miocene vertebrate localities of Nikiti (Chalkidiki Peninsula, Macedonia, Greece): Artiodactyla. Geobios 49, 119 ï 134. 
Kostopoulos, D.S., 2009. The Late Miocene mammal faunas of the Mytilinii Basin, Samos Island, Greece: new collection. 13. Giraffidae. Beitr. Zur Paläontol. 31, 299 ï 343.

Kostopoulos, D.S., Koliadimou, K.K., Koufos, G.D., 1996. The giraffids from the Late Miocene mammalian localities of Nikiti (Macedonia, Greece). Palaeontogr. Abt. -Stuttg.- 239, $611 ̈ 88$.

Kostopoulos, D.S., Sen, S., 2016. Suidae, Tragulidae, Giraffidae, and Bovidae. Geodiversitas 38, $273 \ddot{i ̈} 298$.

Koufos, G.D., 2009. The Late Miocene mammal faunas of the Mytilinii Basin, Samos Island, Greece: new collection. 1. History of the Samos Fossil Mammals. Beitr. Zur Paläontol. 31, 1ï 12.

Koufos, G.D., 2006. The Neogene mammal localities of Greece: faunas, chronology and biostratigraphy. Hell. J. Geosci. 41, $183 і ̈ 214$.

Le Quellec, J.-L., 1999. Répartition de la grande faune sauvage dans le nord de lôAfrique durant lâHolocène. Anthropol.-PARIS- 103, $161 і ̈ 176$.

Leuthold, B.M., 1978. Ecology of the giraffe in Tsavo East National Park, Kenya. East Afr. Wildl. J. 16, 1ї 20.

Lumpkin, S., Kranz, K.R., 1984. Cephalophus sylvicultor. Mamm. Species 225, 1 ï 7.

Malenky, R.K., Wrangham, R.W., 1994. A quantitative comparison of terrestrial herbaceous food consumption by Pan paniscus in the Lamako forest, Zaire, and Pan troglodytes in the Kibale forest, Uganda. Am. J. Primatol. 32, 1 ï 12.

Mecquenem, R. de, 1924. Contribution à lấtude des fossiles de Maragha. Ann. Paléontol. Vertébrés 13/14, $135 \mathrm{I} 160$.

Merceron, G., Ramdarshan, A., Blondel, C., Boisserie, J.-R., Brunetiere, N., Francisco, A., Gautier, D., Milhet, X., Novello, A., Pret, D., 2016. Untangling the environmental from the dietary: dust does not matter. Proceeding R. Soc. Lond. B 283, 20161032. 
559

560

561

562

563

564

565

566

567

568

569

570

571

572

573

574

575

576

577

578

579

580

581

582

583

Mihlbachler, M.C., Beatty, B.L., 2012. Magnification and resolution in dental microwear analysis using light microscopy. Paleontol Electron. 15, 25A.

Mihlbachler, M.C., Beatty, B.L., Caldera-Siu, A., Chan, D., Lee, R., 2012. Error rates and observer bias in dental microwear analysis using light microscopy. Palaeontol. Electron. 15, 12A.

OâConnor, D.A., Butt, B., Foufopoulos, J.B., 2015. Foraging ecologies of giraffe (Giraffa camelopardalis reticulata) and camels (Camelus dromedarius) in northern Kenya: effects of habitat structure and possibilities for competition? Afr. J. Ecol. 53, 183 İ 193. https://doi.org/10.1111/aje.12204

Parker, D.M., Bernard, R.T.F., Colvin, S.A., 2003. The diet of a small group of extralimital giraffe. Afr. J. Ecol. 41, 245.

Purnell, M., Seehausen, O., Galis, F., 2012. Quantitative three-dimensional microtextural analyses of tooth wear as a tool for dietary discrimination in fishes. J. R. Soc. Interface 9, $2225 \ddot{1} 2233$.

Purnell, M.A., Crumpton, N., Gill, P.G., Jones, G., Rayfield, E.J., 2013. Within-guild dietary discrimination from 3-D textural analysis of tooth microwear in insectivorous mammals. J. Zool. 291, $249 і ̈ 257$.

Purnell, M.A., Darras, L.P.G., 2016. 3D tooth microwear texture analysis in fishes as a test of dietary hypotheses of durophagy. Surf. Topogr. Metrol. Prop. 4, 014006. https://doi.org/10.1088/2051-672X/4/1/014006

Ramdarshan, A., Blondel, C., Brunetière, N., Francisco, A., Gautier, D., Surault, J., Merceron, G., 2016. Seeds, browse, and tooth wear: a sheep perspective. Ecol. Evol. 6, 5559ї 5569.

Ríos, M., Sánchez, I.M., Morales, J., 2017. A new giraffid (Mammalia, Ruminantia, Pecora) from the late Miocene of Spain, and the evolution of the sivathere-samothere lineage. PLOS ONE 12, e0185378. https://doi.org/10.1371/journal.pone.0185378 
Ríos, M., Sánchez, I.M., Morales, J., 2016. Comparative anatomy, phylogeny, and systematics of the Miocene giraffid Decennatherium pachecoi Crusafont, 1952 (Mammalia, Ruminantia, Pecora): State of the art. J. Vertebr. Paleontol. 36, e1187624. https://doi.org/10.1080/02724634.2016.1187624

Scott, J.R., 2012. Dental microwear texture analysis of extant African Bovidae. Mammalia 76, $157 \ddot{1} 174$.

Scott, K.M., 1990. Postcranial dimensions of ungulates as predictors of body mass. Body Size Mamm. Paleobiology Estim. Biol. Implic. 30, 1 ï 335.

Scott, R.S., Ungar, P., Bergstrom, T.S., Brown, C.A., Childs, B.E., Teaford, M.F., Walker, A., 2006. Dental microwear texture analysis: technical considerations. J. Hum. Evol. 51, 339ï 349.

Sen, S., 1998. The age of the Molayan mammals locality, Afghanistan. Geobios 31, 385ï 391. Senyürek, M.S., 1954. A study of the remains of Samotherium found at - Recherche Google. Rev. Fac. Lang. Hist. Géographie Univ. Ank. 12, 1 ï 32.

Sickenberg, O., 1975. Die Gliederung des höheren Jungtertiärs und Altquartärs-in der Türkei nach Vertebraten und ihre Bedeutung für die-internationale Neogen-Gliederung. Geol. Jahrb. Reihe B 1ї 167.

Sokal, S.R., Rohlf, F.J., 1969. Biometry. W. E. Freeman and Company, New York.

Solounias, N., 1988. Evidence from horn morphology on the phylogenetic relationship of the Pronghorn (Antilocapra americana). J. Mammal. 69, 140 Ï 143.

Solounias, N., 1981. Mammalian fossils of Samos and Pikermi. Part 2. Resurrection of a classic turolian fauna. Ann. Carnegie Mus. 50, 231 ï 269.

Solounias, N., Danowitz, M., 2016. The Giraffidae of Maragheh and the identification of a new species of Honanotherium. Palaeobiodiversity Palaeoenvironments 96, 489-506. 
608

609

610

611

612

613

614

615

616

617

618

619

620

621

622

623

624

625

626

627

628

629

630

Solounias, N., Dawson-Saunders, B., 1988. Dietary adaptations and paleoecology of the late Miocene ruminants from Pikermi and Samos in Greece. Palaeogeogr. Palaeoclimatol. Palaeoecol. 65, 149ї 172.

Solounias, N., Mac Graw, W.S., Hayek, L.-A., Werdelin, L., 2000. The paleodiet of the Giraffidae, in: Vrba, E.S., Schaller, G.B. (Eds.), Antelopes, Deer, and Relatives. Yale University Press, New Haven, pp. $84 і ̈ 95$.

Solounias, N., Rivals, F., Semprebon, G.M., 2010. Dietary interpretation and paleoecology of herbivores from Pikermi and Samos (late Miocene of Greece). Paleobiology 36, $113 \mathrm{i} 136$. https://doi.org/10.1666/0094-8373-36.1.113

Solounias, N., Teaford, M.F., Walker, A., 1988. Interpreting the diet of extinct ruminants $\mathbb{E}$ the case of a non-browsing giraffid. Paleobiology 14, $287 i ̈ 300$.

Spassov, N., 2002. The Turolian Megafauna of West Bulgaria and the character of the Late Miocene ñPikermian biome.ò Bull. Della Soc. Paleontol. Ital. 41, 69 ï 81.

Thenius, E., 1992. Das Okapi (Mammalia, Artiodactyla) von Zaire - Ălebendes Fossilò oder sekundärer Urwaldbewohner? J. Zool. Syst. Evol. Res. 30, 163 Ï 179. https://doi.org/10.1111/j.1439-0469.1992.tb00166.x

Williamson, E.A., Tutin, C.E.G., Rogers, M.E., Fernandez, M., 1990. Composition of the diet of lowland gorillas at Lopé in Gabon. Am. J. Phys. Anthropol. 21, 265 ï 277.

Wilson, D.E., Reeder, D.M., 2005. Mammal species of the world: a taxonomic and geographic reference. JHU Press.

Wrangham, R.W., Conklin, N.L., Chapman, C.A., Hunt, K.D., 1991. The significance of fibrous foods for Kibale forest chimpanzees. Philos. Transl. R. Soc. Lond. 334, 171 ï 178. 
Table 1. Descriptive statistics of dental microwear textural parameters of modern ruminants and extinct species of giraffids.

\begin{tabular}{|c|c|c|c|c|c|c|c|c|}
\hline & & & \multicolumn{2}{|c|}{ Asfc* } & \multicolumn{2}{|c|}{ epLsar $\left(\times 10^{-3}\right)$} & \multicolumn{2}{|c|}{ HAsfc } \\
\hline & Taxa & $N$ & $\mathrm{~m}$ & sd & $\mathrm{m}$ & sd & $\mathrm{m}$ & sd \\
\hline \multirow{5}{*}{ Modern species } & Cephalophus silvicultor & 25 & 4.03 & 3.25 & 3.07 & 1.58 & 0.54 & 0.30 \\
\hline & Giraffa sp. & 12 & 2.51 & 1.48 & 2.10 & 1.57 & 0.35 & 0.12 \\
\hline & Cervus elaphus & 29 & 2.12 & 0.80 & 4.59 & 1.91 & 0.55 & 0.25 \\
\hline & Okapia johnstoni & 25 & 2.46 & 1.46 & 4.07 & 2.07 & 0.52 & 0.27 \\
\hline & Alcelaphus buselaphus & 28 & 1.60 & 0.77 & 5.80 & 1.64 & 0.39 & 0.12 \\
\hline \multirow{10}{*}{ Extinct species } & Bohlinia attica & 5 & 1.47 & 0.73 & 2.47 & 0.94 & 0.49 & 0.11 \\
\hline & Helladotherium duvernoyi & 15 & 2.46 & 1.23 & 2.99 & 1.37 & 0.43 & 0.52 \\
\hline & Palaeogiraffa macedoniae & 6 & 2.61 & 0.65 & 5.13 & 2.63 & 0.36 & 0.14 \\
\hline & Palaeogiraffa major & 1 & 2.87 & - & 6.41 & - & 0.38 & - \\
\hline & Palaeogiraffa paimiri & 6 & 1.68 & 0.93 & 1.92 & 0.97 & 0.51 & 0.29 \\
\hline & Samotherium neumayri & 1 & 0.66 & - & 1.99 & - & 0.15 & - \\
\hline & Palaeotragus rouenii & 21 & 2.30 & 1.06 & 3.80 & 1.63 & 0.35 & 0.11 \\
\hline & cf. P. coelophrys & 3 & 1.84 & 0.93 & 3.60 & 2.43 & 0.34 & 0.07 \\
\hline & Samotherium boissieri & 5 & 2.43 & 1.33 & 4.97 & 2.10 & 0.37 & 0.14 \\
\hline & Samotherium major & 9 & 2.89 & 1.63 & 3.70 & 1.63 & 0.37 & 0.25 \\
\hline
\end{tabular}

634

$635 *$ all of these three parameters are dimensionless (see Scott et al., 2006); m: mean; sd: standard deviation; Asfc:

636 complexity; epLsar: anisotropy (calculated at the $1.8 \mu \mathrm{m}$ scale); HAsfc: Heterogeneity of complexity (calculated 637 with a 9-cell mesh). 
Table 2. Analysis of variance on rank-transformed variables.

639

\begin{tabular}{|c|c|c|c|c|c|}
\hline Asfc & $\begin{array}{c}d f \\
14 \\
176\end{array}$ & $\begin{array}{c}\text { SS } \\
115848.3 \\
464791.7\end{array}$ & $\begin{array}{c}\text { MS } \\
8274.9 \\
2640.9\end{array}$ & $\begin{array}{c}\mathrm{F} \\
3.1334\end{array}$ & $\begin{array}{c}p \\
0.0002\end{array}$ \\
\hline epLsar & $\begin{array}{r}d f \\
14 \\
176\end{array}$ & $\begin{array}{c}\text { SS } \\
176760.3 \\
403878.7\end{array}$ & $\begin{array}{c}\text { MS } \\
12625.7 \\
2294.8\end{array}$ & $\begin{array}{c}\mathrm{F} \\
5.5020\end{array}$ & $\begin{array}{c}P \\
0.0000\end{array}$ \\
\hline HAsfc & $\begin{array}{c}d f \\
14 \\
176\end{array}$ & $\begin{array}{c}\text { SS } \\
109086.9 \\
471552.1\end{array}$ & $\begin{array}{c}\text { MS } \\
7791.9 \\
2679.3\end{array}$ & $\begin{array}{c}\mathrm{F} \\
2.9082\end{array}$ & $\begin{array}{c}P \\
0.0005\end{array}$ \\
\hline
\end{tabular}

640 Asfc: complexity; epLsar: anisotropy (calculated at the $1.8 \mu \mathrm{m}$ scale); HAsfc: Heterogeneity of complexity

641 (calculated with a 9-cell mesh).; SS: sum of squares; MS: mean of squares; F: F statistic; p: p-value

642 
Table 3. Post-hoc test of comparisons (the Fisher Least Significant Differences and the conservative Tukey Honest Significant Differences test).

\begin{tabular}{|c|c|c|c|c|c|c|c|c|c|c|c|c|c|c|}
\hline & 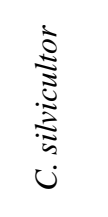 & 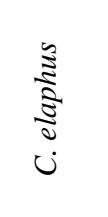 & 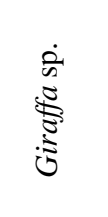 & 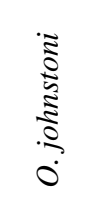 & 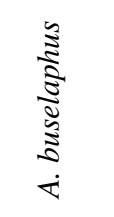 & 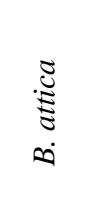 & 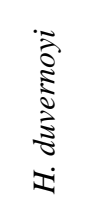 & 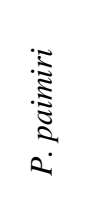 & 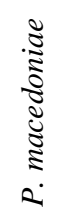 & $\begin{array}{c}\grave{a} \\
\stackrel{5}{\vdots} \\
\text { a. }\end{array}$ & 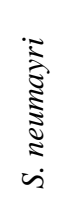 & 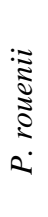 & 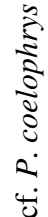 & 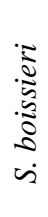 \\
\hline Cervus elaphus & $\begin{array}{c}\text { Asfc } \\
\text { epLsar }\end{array}$ & & & & & & & & & & & & & \\
\hline Giraffa sp. & HAsfc & $\begin{array}{l}\text { HAsfc } \\
\text { epLsar }\end{array}$ & & & & & & & & & & & & \\
\hline $\begin{array}{c}\text { Okapia } \\
\text { johnstoni }\end{array}$ & $\begin{array}{c}\text { Asfc } \\
\text { epLsar }\end{array}$ & & $\begin{array}{l}\text { HAsfc } \\
\text { epLsar }\end{array}$ & & & & & & & & & & & \\
\hline $\begin{array}{l}\text { Alcelaphus } \\
\text { buselaphus }\end{array}$ & $\begin{array}{l}\text { Asfc } \\
\text { epLsar }\end{array}$ & $\begin{array}{l}\text { HAsfc } \\
\text { Asfc } \\
\text { epLsar }\end{array}$ & $\begin{array}{c}\text { Asfc } \\
\text { epLsar }\end{array}$ & $\begin{array}{l}\text { HAsfc } \\
\text { Asfc } \\
\text { epLsar }\end{array}$ & & & & & & & & & & \\
\hline Bohlinia attica & $\underline{\text { Asfc }}$ & epLsar & HAsfc & & epLsar & & & & & & & & & \\
\hline $\begin{array}{c}\text { Helladotherium } \\
\text { duvernoyi }\end{array}$ & $\begin{array}{l}\text { HAsfc } \\
\text { Asfc }\end{array}$ & $\frac{\text { HAsfc }}{\text { epLsar }}$ & & HAsfc & $\begin{array}{c}\text { Asfc } \\
\text { epLsar } \\
\end{array}$ & HAsfc & & & & & & & & \\
\hline $\begin{array}{c}\text { Palaeogiraffa } \\
\text { paimiri }\end{array}$ & Asfc & epLsar & & epLsar & epLsar & & & & & & & & & \\
\hline $\begin{array}{c}\text { Palaeogiraffa } \\
\text { macedoniae }\end{array}$ & epLsar & HAsfc & epLsar & & Asfc & $\begin{array}{c}\text { Asfc } \\
\text { epLsar }\end{array}$ & epLsar & epLsar & & & & & & \\
\hline $\begin{array}{c}\text { Palaeogiraffa } \\
\text { major }\end{array}$ & & & epLsar & & & epLsar & & epLsar & & & & & & \\
\hline $\begin{array}{c}\text { Samotherium } \\
\text { neumayri }\end{array}$ & $\begin{array}{l}\text { HAsfc } \\
\text { Asfc }\end{array}$ & HAsfc & & HAsfc & epLsar & HAsfc & & & Asfc & & & & & \\
\hline $\begin{array}{c}\text { Palaeotragus } \\
\text { rouenii }\end{array}$ & $\begin{array}{l}\text { HAsfc } \\
\text { Asfc }\end{array}$ & $\underline{\text { HAsfc }}$ & epLsar & HAsfc & $\begin{array}{c}\text { Asfc } \\
\text { epLsar }\end{array}$ & HAsfc & & epLsar & & & & & & \\
\hline $\begin{array}{c}\text { cf. } \\
\text { Palaeotragus } \\
\text { coelophrys }\end{array}$ & Asfc & & & & epLsar & & & & & & & & & \\
\hline $\begin{array}{c}\text { Samotherium } \\
\text { boissieri }\end{array}$ & epLsar & & epLsar & & & epLsar & epLsar & epLsar & & & & & & \\
\hline $\begin{array}{c}\text { Samotherium } \\
\text { major }\end{array}$ & HAsfc & HAsfc & epLsar & HAsfc & $\begin{array}{c}\text { Asfc } \\
\text { epLsar }\end{array}$ & Asfc & & epLsar & & & Asfc & & & \\
\hline
\end{tabular}


Table 4. Body anatomical traits of modern and extinct giraffids.

\begin{tabular}{|c|c|c|c|c|c|c|c|}
\hline & \multicolumn{2}{|c|}{$\begin{array}{c}\text { Metacarpal } \\
\text { length }\end{array}$} & \multicolumn{3}{|c|}{ Body mass estimate } & $\begin{array}{l}\mathrm{Pm} / \mathrm{M} \text { index } \\
\text { (upper teeth) }\end{array}$ & $\begin{array}{l}\text { Pm/M index } \\
\text { (lower teeth) }\end{array}$ \\
\hline Species & $\mathrm{N}$ & $\mathrm{L}$ & $\mathrm{N}$ & $\begin{array}{c}\text { Humerus } \\
\text { W }\end{array}$ & $\begin{array}{l}\text { body } \\
\text { mass }\end{array}$ & & \\
\hline Giraffa sp. & 33 & 701 & 26 & 116 & 1362 & 75 (mean) & 68 (mean) \\
\hline Okapia johnstoni & 2 & 307 & 2 & 75 & 441 & 74,75 & $60,65,70$ \\
\hline Bohlinia attica & 6 & 704 & 7 & 107 & 1118 & $73,76,78$ & - \\
\hline Helladotherium duvernoyi & 20 & 435 & 15 & 141 & 2201 & $77,79,81$ & $63,65,67^{(3)}$ \\
\hline Palaeogiraffa macedoniae & 1 & 465 & 2 & 115 & 1324 & $72,73,75$ & 65 \\
\hline Palaeogiraffa pamiri & 4 & 469 & 1 & 115 & 1324 & $76 ?$ & 68 \\
\hline Palaeotragus coelophrys & 4 & 370 & - & - & - & $70,71,73,74$ & 68 \\
\hline Palaeotragus rouenii & 5 & 409 & $6^{(2)}$ & 75 & 439 & 70,74 & $63,67,68$ \\
\hline Samotherium boissieri & $14^{(2)}$ & 357 & $4^{(2)}$ & 104 & 1022 & $67.5(\text { mean of } 7)^{(1)}$ & $57,59,60,60$ \\
\hline Samotherium major & $32^{(2)}$ & 417 & $7^{(2)}$ & 141 & 2185 & $65,67,68^{(4)}$ & 63,66 \\
\hline Samotherium neumayri & 11 & 382 & 4 & 116 & 1341 & 65 & 58,67 \\
\hline
\end{tabular}

Metacarpal length (in $\mathrm{mm}$ ), body mass (in $\mathrm{kg}$ ) based upon humerus distal articular width (in $\mathrm{mm}$ ) following the equation of Scott (1990) for Ruminants (body mass $=10^{\left(2.5518^{*} \log (\text { Humerus } \mathrm{W})+0.4093\right)}$ ), indexes of upper and lower premolar/molar rows of modern and extinct giraffids. Most data are our own, with a few additions from Bohlin $\left(1926^{(1)}\right)$, Kostopoulos $\left(2009^{(2)}, 2016^{(3)}\right)$ and Senyürek $\left(1954^{(4)}\right)$. 


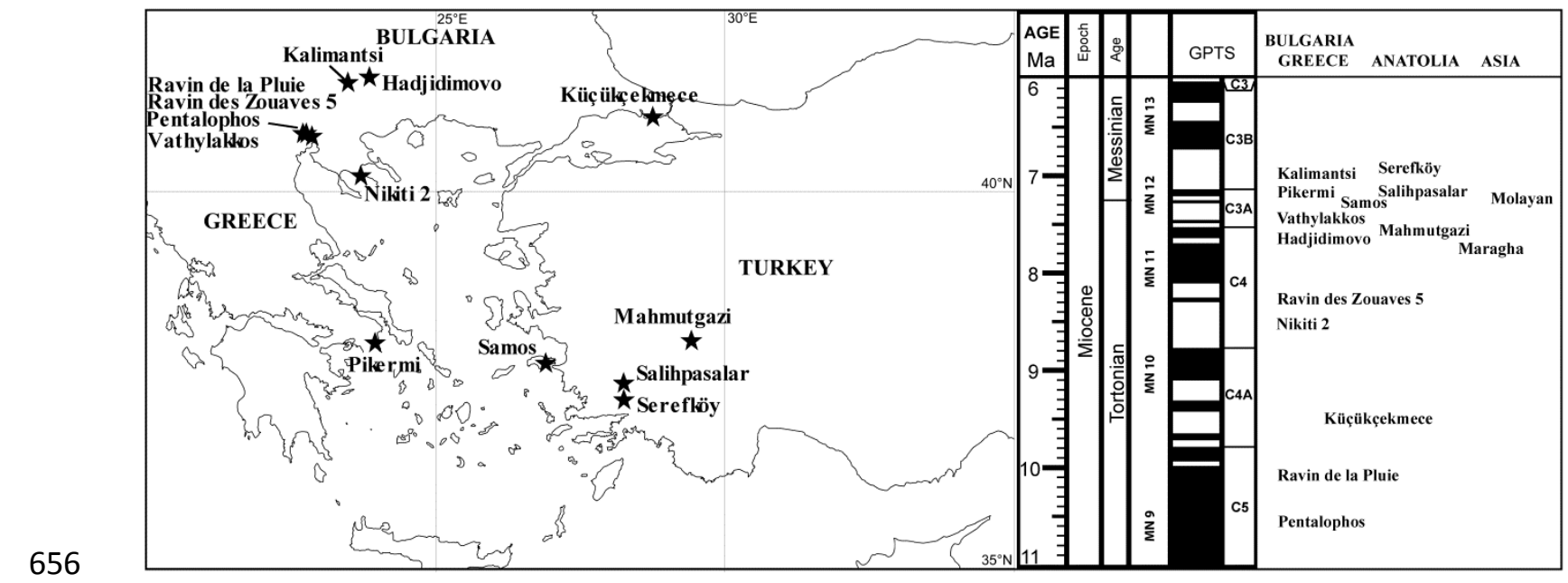

657 Figure 1. Geographic and chronostratigraphic distribution of the main localities considered in 658 this study. A few specimens come from Asian (Maragha in Iran and Molayan in Afghanistan) 659 and North African (Douaria in Tunisia) localities outside the map. 

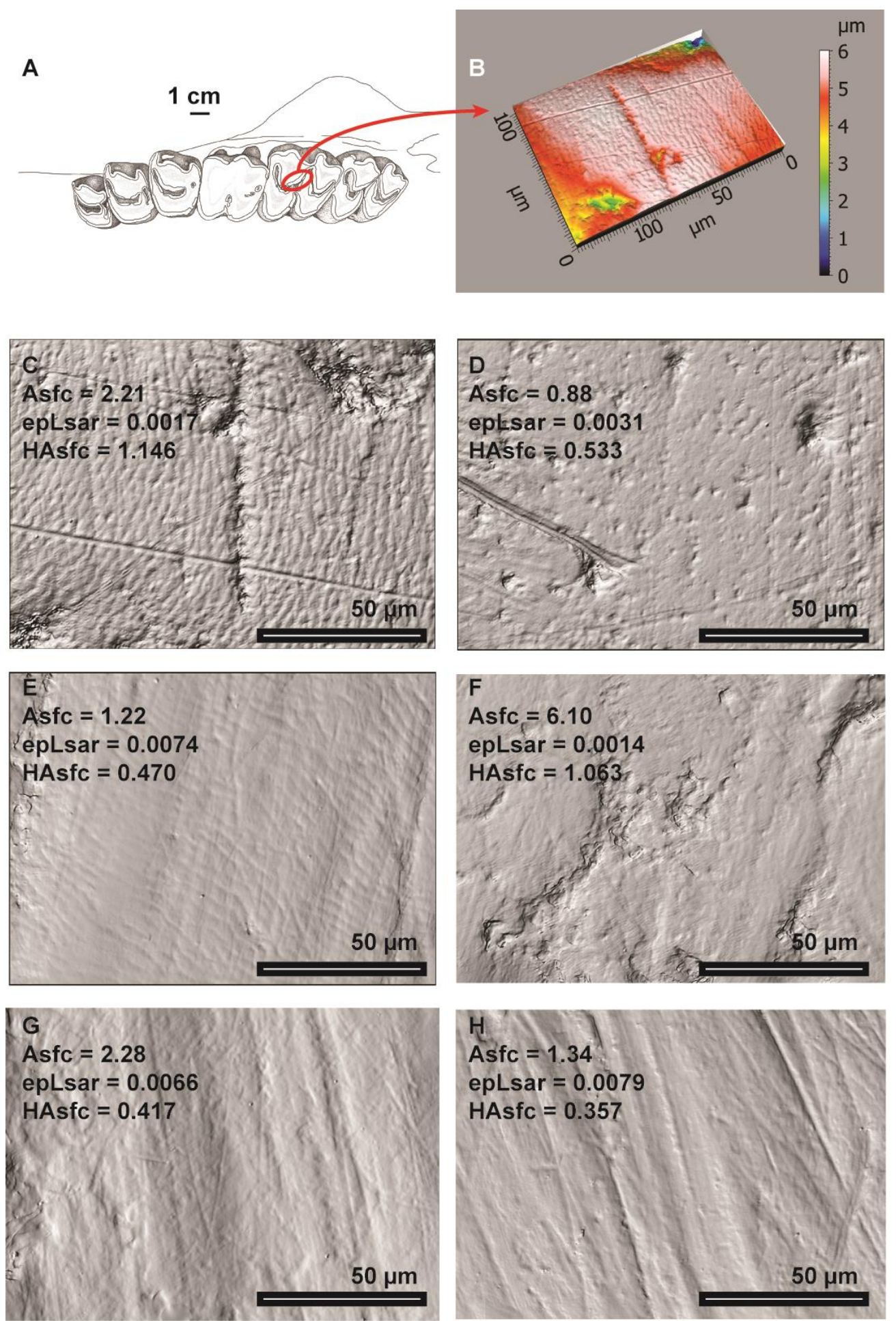

662 Figure 2. Occlusal view of left upper molar of a modern giraffe, Giraffa sp. (A; UP-M10-5-

663 001-A) and 3D surface simulation on shearing dental facet (B; NHMB-Z553). The

664 photosimulations C-H were generated through the LeicaMap 7.0: Giraffa sp. (C: NHMB-

665 Z553), Okapia johnstoni (D: NHMB-Z245; E: NHMB-Z1085), Cephalophus silvicultor (F:

666 NHMB-1611), Cervus elaphus (G: UP-Chat-9-4168) and Alcelaphus buselaphus (H: UP-

667 ART8-21). 

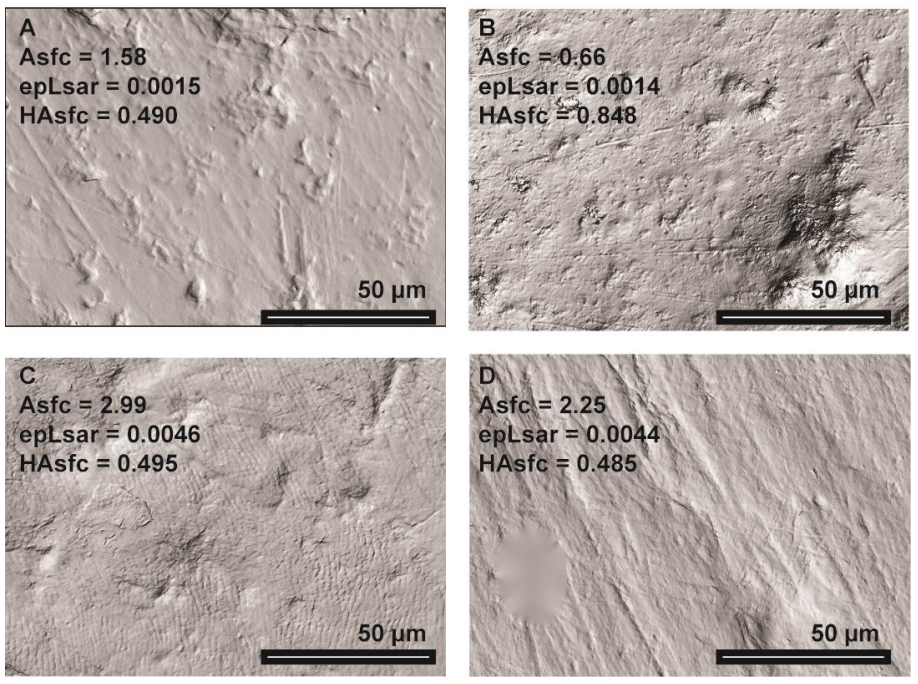

670 Figure 3. The photosimulations A-D were generated through the LeicaMap 7.4:

671 Helladotherium duvernoyi from Kalimansti, Bulgaria (A; K5159), Palaeogiraffa pamiri from 672 Küçükçekmeçe, Turkey (B; MNHN-TRQ-430), Palaeotragus rouenii from Pikermi, Greece 673 (C; MNHN-PIK-1672), and Samotherium major from Salihpasalar, Turkey (D; MTA-MYS674 843).

675 
Cervus elaphus UP - Chat-9-4168-scan D Asfc $=\mathbf{2 . 2 8}$ epLsar $=0.0066$

Alcelaphus buselaphus UP-ART 8-21-scan B Asfc $=1.34$ epLsar $=0.0079$

Cephalophus silviculto NHMB-319-scan C Asfc $=2.29$ epLsar $=0.0047$

Giraffa camelopardalis NHMB-Z553-scan D Asfc $=2.21$ epLsar $=0.0017$

Okapia johnstoni NHMB-Z1085-scan A Asfc $=1.22$ epLsar $=0.0074$
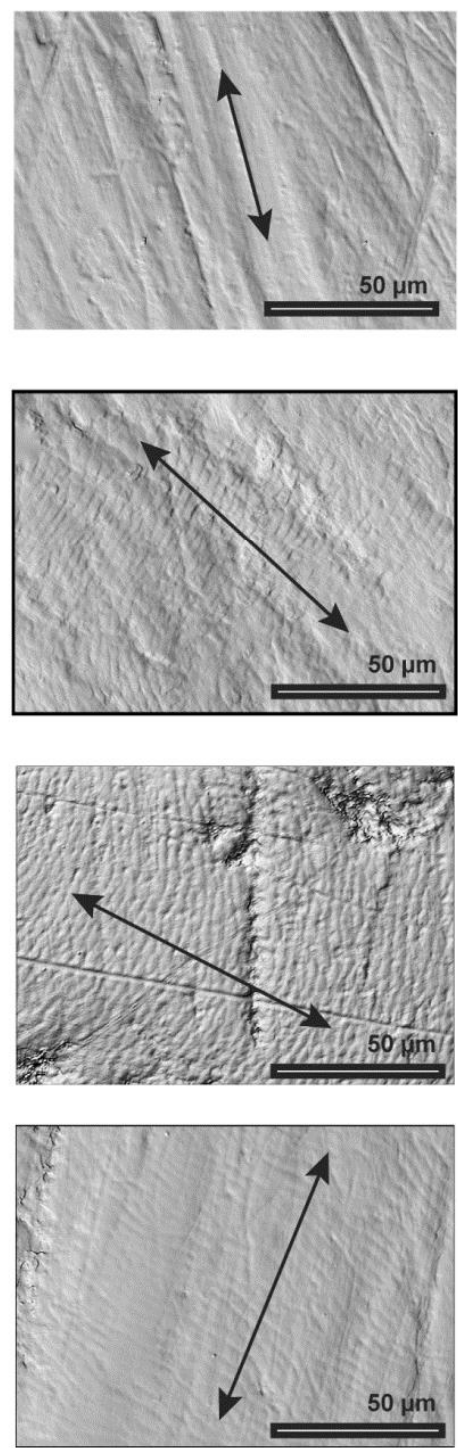

Normalized Vectors Plot
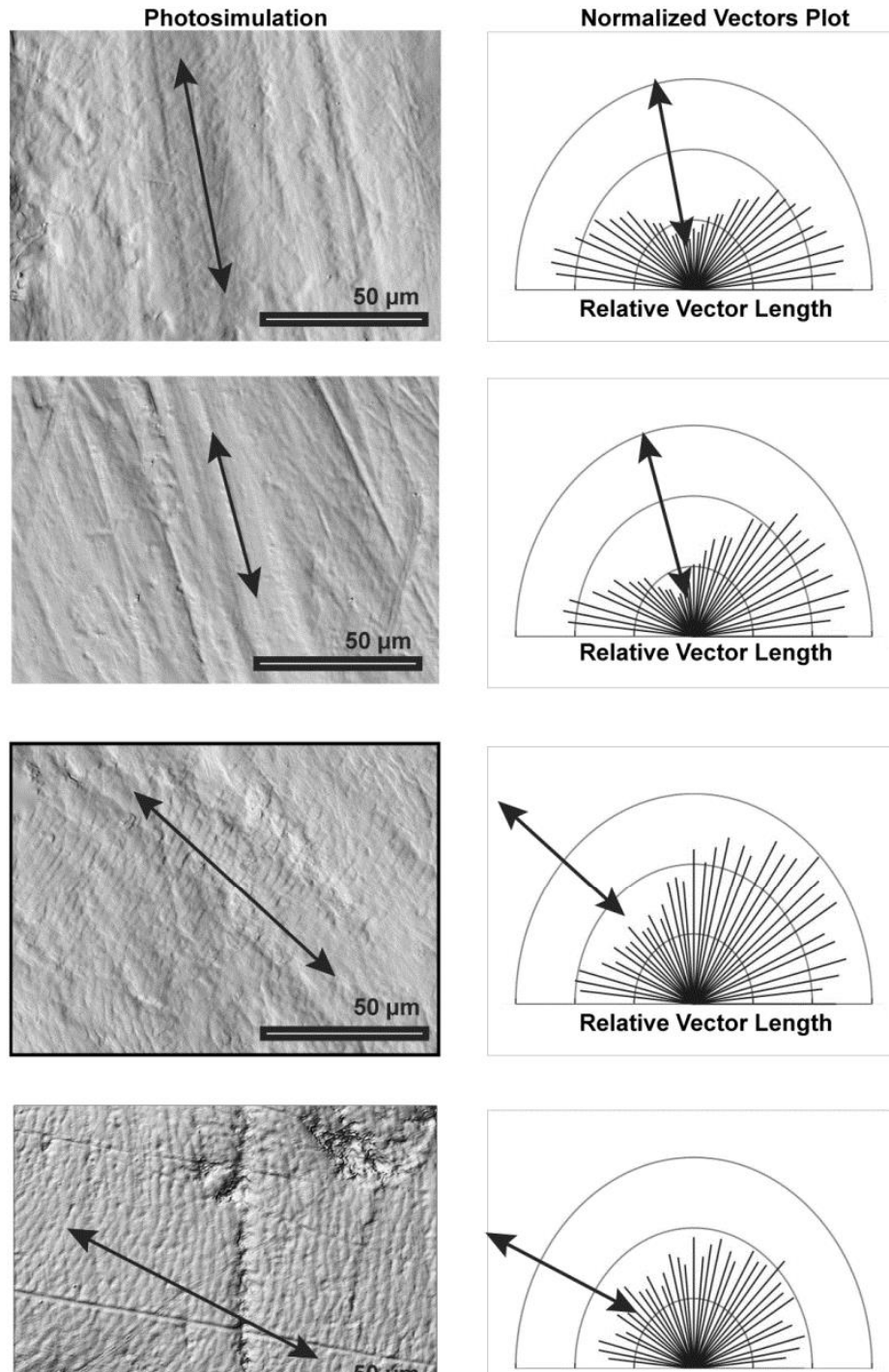

Relative Vector Length

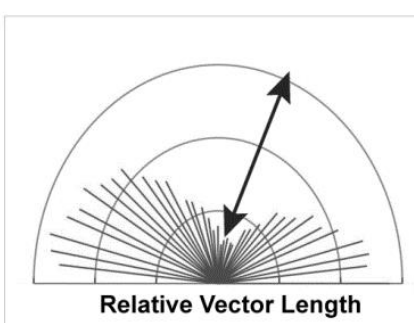

Figure 4. Photosimulations of dental microwear textures of modern ruminants with values in complexity (Asfc) and anisotropy (epLsar) and the corresponding rosette plot of relative lengths taken at 36 different orientations. The two first surfaces (Cervus elaphus and Alcelaphus buselaphus) display low relative length correlated with the main microwear textural orientation (here the main directionality is highlighted with the black arrows). The last three surfaces (Cephalophus silvicultor, Giraffa camelopardalis and Okapia johnstoni) display a main orientation of dental microwear textures disconnected from the perikemata direction, meaning that anisotropy does not reflect the perikemata directionality, but the dental microwear texture one. 

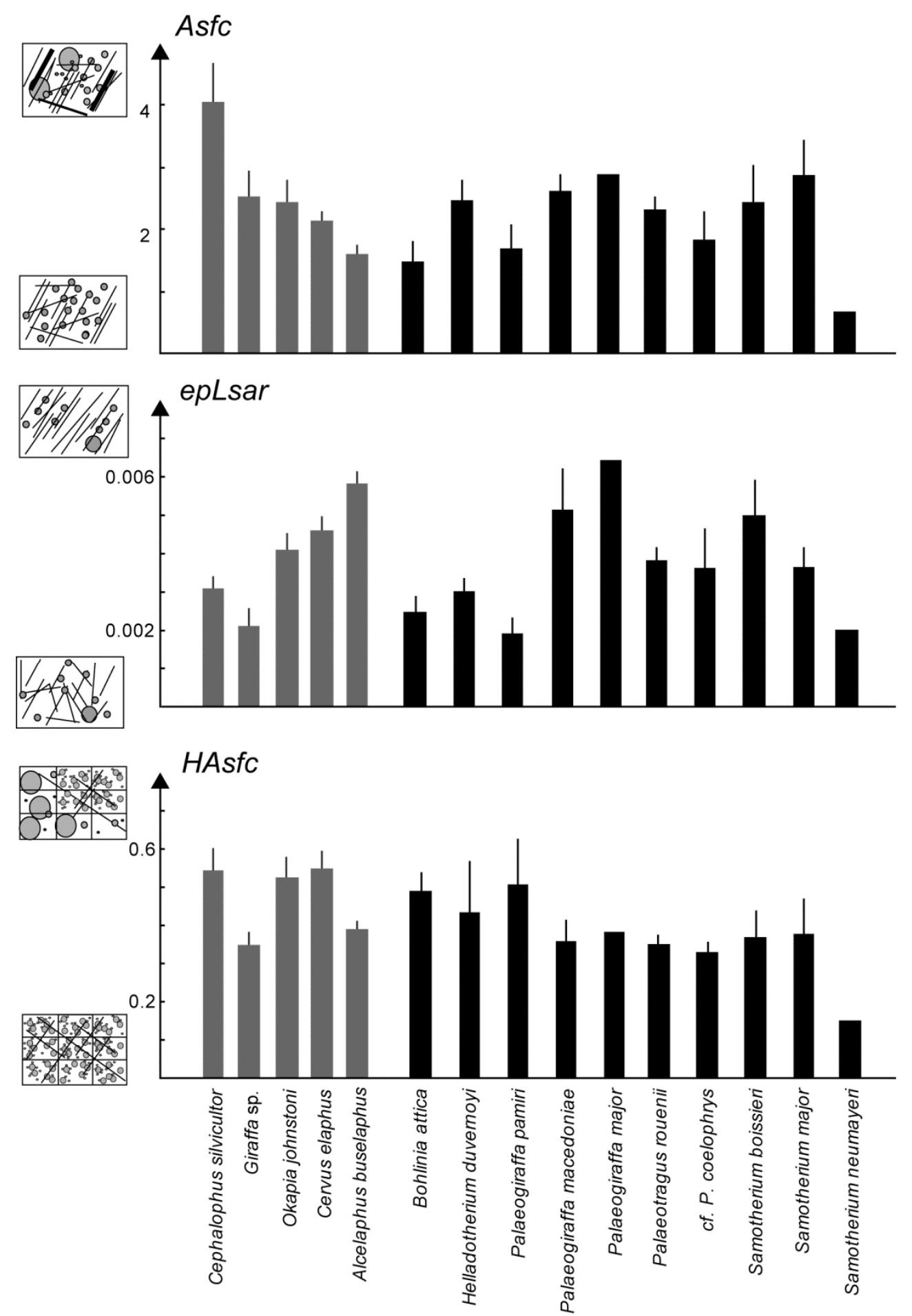

Figure 5. Bar plots (mean and standard error of the mean) of dental microwear textural 689 parameters Asfc: complexity; epLsar: anisotropy calculated at the $1.8 \mu \mathrm{m}$ scale; HAsfc:

690 Heterogeneity of complexity (calculated with a 9-cell mesh) for modern ruminants (in gray) 691 and extinct giraffids (in black). 


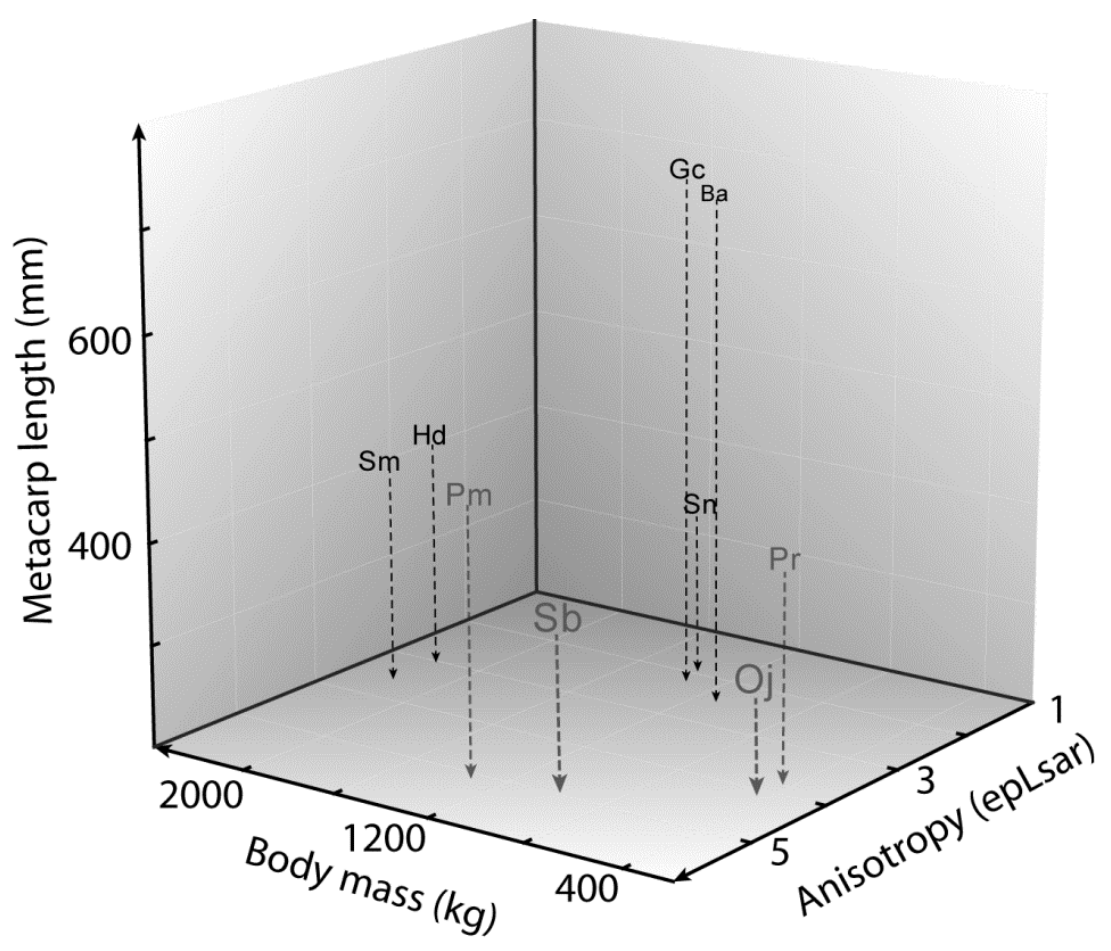

694 Figure 6. 3D plot of the average of anisotropy (epLsar) of the dental microwear textures vs. 695 averages of body mass (in $\mathrm{kg}$ ) and length of metacarpal bone (in $\mathrm{mm}$ ), which approximates 696 the height at the withers. Note that specimens used for body traits and dental microwear 697 analysis are not the same (see Table 4). 


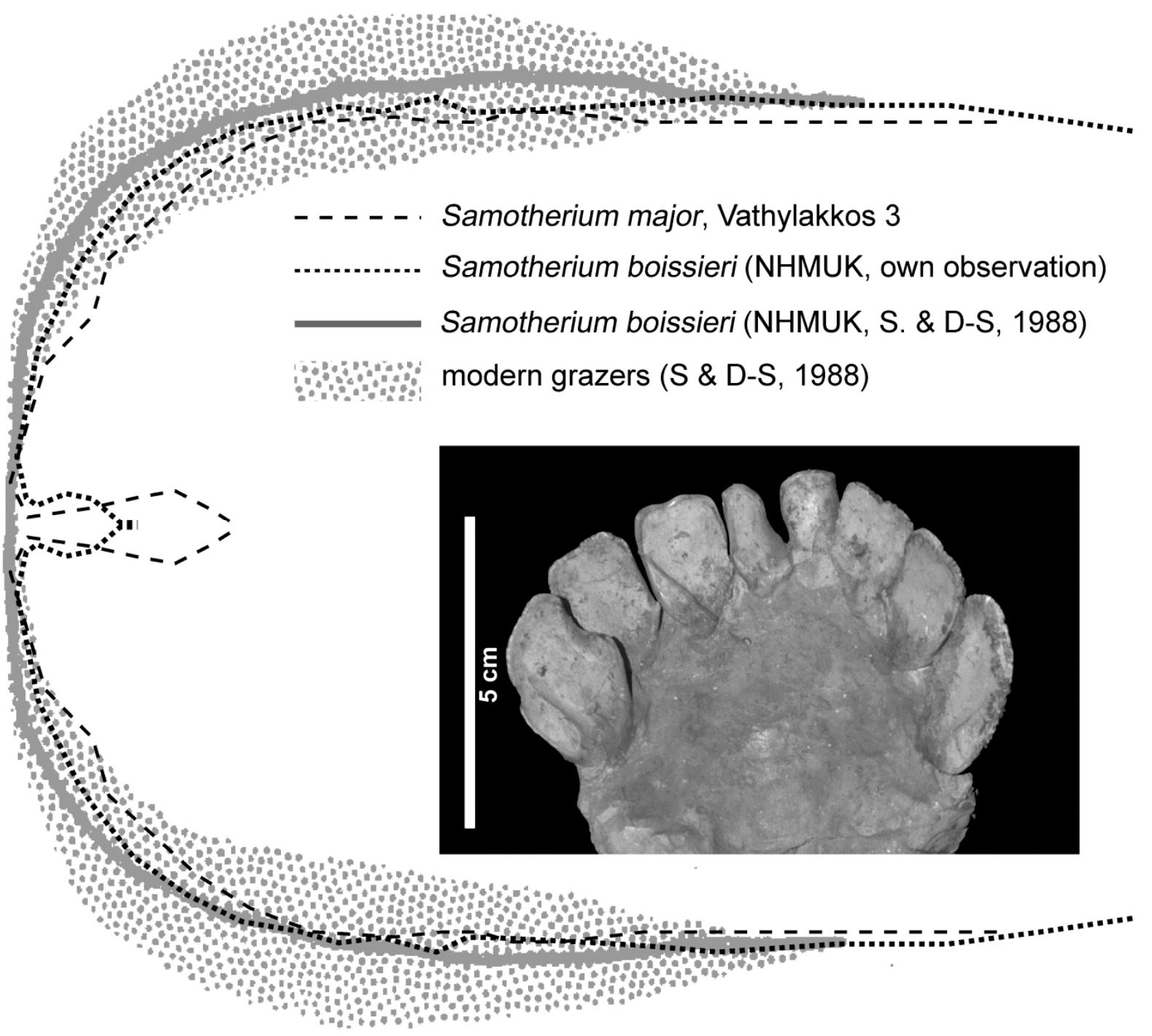

700 Figure 7. Outlines of the premaxilla in Samotherium. Square outline denotes grazers. S \& DS: Solounias and Dawson-Saunders (1988); outline of $S$. major based upon the specimen from Vathylakkos 3 (Geraads, 1978); outlines of S. boissieri based upon NHMUK M4215. 


\begin{tabular}{|c|c|c|c|c|c|}
\hline State & Species & Individual & Asfc & \multicolumn{2}{|c|}{ epLsar $1.8 \mu \mathrm{m}$ Hasfc 9 cells } \\
\hline Extant species & Alcelaphus buselaphus & MNHN-1894-1524 & 1.56 & 0.00480 & 0.381 \\
\hline Extant species & Alcelaphus buselaphus & MNHN-1913-39 & 0.52 & 0.00166 & 0.491 \\
\hline Extant species & Alcelaphus buselaphus & MNHN-1913-744 & 0.87 & 0.00339 & 0.297 \\
\hline Extant species & Alcelaphus buselaphus & MNHN-1965-1099 & 1.52 & 0.00736 & 0.272 \\
\hline Extant species & Alcelaphus buselaphus & MNHN-1965-1101 & 0.73 & 0.00398 & 0.405 \\
\hline Extant species & Alcelaphus buselaphus & MNHN-1965-1104 & 1.16 & 0.00545 & 0.519 \\
\hline Extant species & Alcelaphus buselaphus & MNHN-1965-1105 & 1.02 & 0.00491 & 0.199 \\
\hline Extant species & Alcelaphus buselaphus & MNHN-1965-1107 & 1.08 & 0.00525 & 0.270 \\
\hline Extant species & Alcelaphus buselaphus & MNHN-1970-31 & 1.97 & 0.00709 & 0.366 \\
\hline Extant species & Alcelaphus buselaphus & MNHN-1970-34 & 1.94 & 0.00740 & 0.312 \\
\hline Extant species & Alcelaphus buselaphus & MNHN-1970-35 & 1.76 & 0.00517 & 0.424 \\
\hline Extant species & Alcelaphus buselaphus & MNHN-1974-211 & 1.19 & 0.00564 & 0.329 \\
\hline Extant species & Alcelaphus buselaphus & MNHN-BUB-6 & 0.87 & 0.00360 & 0.249 \\
\hline Extant species & Alcelaphus buselaphus & MNHN-BUB-8 & 2.40 & 0.00417 & 0.446 \\
\hline Extant species & Alcelaphus buselaphus & SMNK-1027 & 1.14 & 0.00507 & 0.302 \\
\hline Extant species & Alcelaphus buselaphus & SMNK-1206 & 1.29 & 0.00680 & 0.791 \\
\hline Extant species & Alcelaphus buselaphus & SMNK-1207 & 1.18 & 0.00796 & 0.333 \\
\hline Extant species & Alcelaphus buselaphus & SMNK-126 & 0.94 & 0.00706 & 0.339 \\
\hline Extant species & Alcelaphus buselaphus & SMNK-2358 & 2.40 & 0.00759 & 0.401 \\
\hline Extant species & Alcelaphus buselaphus & SMNK-47 & 1.72 & 0.00673 & 0.345 \\
\hline Extant species & Alcelaphus buselaphus & UP-ART-8-22 & 3.53 & 0.00622 & 0.344 \\
\hline Extant species & Alcelaphus buselaphus & UP-ART-8-26 & 2.57 & 0.00529 & 0.608 \\
\hline Extant species & Alcelaphus buselaphus & UP-ART-8-27 & 3.69 & 0.00555 & 0.561 \\
\hline Extant species & Alcelaphus buselaphus & UP-ART-8-20 & 1.48 & 0.00610 & 0.400 \\
\hline Extant species & Alcelaphus buselaphus & UP-ART-8-21 & 1.34 & 0.00796 & 0.357 \\
\hline Extant species & Alcelaphus buselaphus & UP-ART-8-23 & 1.24 & 0.00650 & 0.358 \\
\hline Extant species & Alcelaphus buselaphus & UP-ART-8-24 & 2.05 & 0.00913 & 0.399 \\
\hline Extant species & Alcelaphus buselaphus & UP-ART-8-25 & 1.71 & 0.00466 & 0.361 \\
\hline Extant species & Cephalophus silivicultor & NHMB-Csilv-14 & 8.18 & 0.00175 & 0.504 \\
\hline Extant species & Cephalophus silivicultor & NHMB-Csilv-1611 & 2.96 & 0.00607 & 0.289 \\
\hline Extant species & Cephalophus silivicultor & NHMB-Csilv-1612 & 2.65 & 0.00101 & 0.520 \\
\hline Extant species & Cephalophus silivicultor & NHMB-Csilv-1616 & 2.11 & 0.00290 & 0.497 \\
\hline Extant species & Cephalophus silivicultor & NHMB-Csilv-1617 & 3.51 & 0.00428 & 0.467 \\
\hline Extant species & Cephalophus silivicultor & NHMB-Csilv-319 & 4.11 & 0.00288 & 1.325 \\
\hline Extant species & Cephalophus silivicultor & NHMB-Csilv-366 & 2.21 & 0.00615 & 0.384 \\
\hline Extant species & Cephalophus silivicultor & NHMB-Csilv-578 & 3.32 & 0.00256 & 0.813 \\
\hline Extant species & Cephalophus silivicultor & NHMB-Csilv-878 & 6.06 & 0.00139 & 1.089 \\
\hline Extant species & Cephalophus silivicultor & NHMB-Csilv-924 & 2.07 & 0.00426 & 0.317 \\
\hline Extant species & Cephalophus silivicultor & NHMB-Csilv-DIE-1 & 17.03 & 0.00063 & 0.605 \\
\hline Extant species & Cephalophus silivicultor & NHMB-Csilv-GM4 & 3.06 & 0.00211 & 0.975 \\
\hline Extant species & Cephalophus silivicultor & NHMB-Csilv-R12923 & 1.45 & 0.00223 & 0.156 \\
\hline Extant species & Cephalophus silivicultor & NHMB-Csilv-R16753 & 2.66 & 0.00191 & 0.427 \\
\hline Extant species & Cephalophus silivicultor & NHMB-Csilv-SN-DIB-95 & 1.52 & 0.00454 & 0.318 \\
\hline Extant species & Cephalophus silivicultor & NHMB-Csilv-Z2039-2 & 2.62 & 0.00209 & 0.280 \\
\hline Extant species & Cephalophus silivicultor & NHMB-Csilv-Z3048 & 7.53 & 0.00153 & 0.283 \\
\hline Extant species & Cephalophus silivicultor & NHMB-Csilv-Z3344 & 2.15 & 0.00460 & 0.359 \\
\hline Extant species & Cephalophus silivicultor & NHMB-Csilv-Z3347 & 3.43 & 0.00460 & 0.623 \\
\hline Extant species & Cephalophus silivicultor & NHMB-Csilv-Z352 & 1.95 & 0.00476 & 0.338 \\
\hline Extant species & Cephalophus silivicultor & NHMB-Csilv-Z3669 & 2.11 & 0.00312 & 0.334 \\
\hline Extant species & Cephalophus silivicultor & NHMB-Csilv-Z3916 & 5.29 & 0.00355 & 0.749 \\
\hline Extant species & Cephalophus silivicultor & NHMB-Csilv-Z3918 & 3.53 & 0.00476 & 0.344 \\
\hline Extant species & Cephalophus silivicultor & NHMB-Csilv-Z404 & 6.10 & 0.00140 & 1.063 \\
\hline Extant species & Cephalophus silivicultor & NHMB-Csilv-Z464 & 3.07 & 0.00170 & 0.455 \\
\hline
\end{tabular}




\begin{tabular}{|c|c|c|c|c|c|}
\hline State & Species & Individual & Asfc & epLsar $1.8 \mu \mathrm{m}$ & asfc 9 cells \\
\hline Extant species & Cervus elaphus & UP-Chat9-1023 & 1.65 & 0.00263 & 1.127 \\
\hline Extant species & Cervus elaphus & UP-Chat9-1024 & 1.02 & 0.00388 & 0.594 \\
\hline Extant species & Cervus elaphus & UP-Chat9-1025 & 1.54 & 0.00400 & 1.229 \\
\hline Extant species & Cervus elaphus & UP-Chat9-1035 & 2.72 & 0.00063 & 1.055 \\
\hline Extant species & Cervus elaphus & UP-Chat9-1037 & 3.17 & 0.00491 & 0.595 \\
\hline Extant species & Cervus elaphus & UP-Chat9-1038 & 1.98 & 0.00646 & 0.311 \\
\hline Extant species & Cervus elaphus & UP-Chat9-1039 & 1.71 & 0.00835 & 0.584 \\
\hline Extant species & Cervus elaphus & UP-Chat9-2054 & 2.92 & 0.00531 & 0.527 \\
\hline Extant species & Cervus elaphus & UP-Chat9-2057 & 3.17 & 0.00523 & 0.742 \\
\hline Extant species & Cervus elaphus & UP-Chat9-3105 & 1.18 & 0.00457 & 0.516 \\
\hline Extant species & Cervus elaphus & UP-Chat9-3132 & 2.69 & 0.00057 & 0.380 \\
\hline Extant species & Cervus elaphus & UP-Chat9-3133 & 1.65 & 0.00391 & 0.486 \\
\hline Extant species & Cervus elaphus & UP-Chat9-4152 & 1.14 & 0.00451 & 0.451 \\
\hline Extant species & Cervus elaphus & UP-Chat9-4157 & 0.95 & 0.00596 & 0.199 \\
\hline Extant species & Cervus elaphus & UP-Chat9-4159 & 1.57 & 0.00567 & 0.196 \\
\hline Extant species & Cervus elaphus & UP-Chat9-4161 & 1.70 & 0.00373 & 0.510 \\
\hline Extant species & Cervus elaphus & UP-Chat9-4167 & 2.49 & 0.00715 & 0.457 \\
\hline Extant species & Cervus elaphus & UP-Chat9-4168 & 2.28 & 0.00655 & 0.417 \\
\hline Extant species & Cervus elaphus & UP-Chat9-4180 & 1.80 & 0.00411 & 0.290 \\
\hline Extant species & Cervus elaphus & UP-Chat9-4189 & 2.79 & 0.00557 & 0.578 \\
\hline Extant species & Cervus elaphus & UP-Chat9-4190 & 1.42 & 0.00511 & 0.467 \\
\hline Extant species & Cervus elaphus & UP-Chat9-4264 & 2.87 & 0.00169 & 0.824 \\
\hline Extant species & Cervus elaphus & UP-Chat9-4271 & 1.86 & 0.00402 & 0.486 \\
\hline Extant species & Cervus elaphus & UP-Chat9-4278 & 1.57 & 0.00688 & 0.589 \\
\hline Extant species & Cervus elaphus & UP-Chat9-4295 & 1.45 & 0.00153 & 0.320 \\
\hline Extant species & Cervus elaphus & UP-Chat9-4302 & 3.69 & 0.00291 & 0.477 \\
\hline Extant species & Cervus elaphus & UP-Chat9-4319 & 3.96 & 0.00547 & 0.551 \\
\hline Extant species & Cervus elaphus & UP-Chat9-4339 & 2.06 & 0.00654 & 0.602 \\
\hline Extant species & Cervus elaphus & UP-Chat9-4354 & 2.43 & 0.00518 & 0.283 \\
\hline Extant species & Giraffa sp. & KNM-no\#-Z7 & 1.43 & 0.00234 & 0.241 \\
\hline Extant species & Giraffa sp. & KNM-OM-2087 & 1.31 & 0.00190 & 0.401 \\
\hline Extant species & Giraffa sp. & KNM-OM-2275 & 2.70 & 0.00141 & 0.190 \\
\hline Extant species & Giraffa sp. & MNHN-1928-307 & 2.90 & 0.00179 & 0.446 \\
\hline Extant species & Giraffa sp. & NHMB-Z-1086 & 1.46 & 0.00613 & 0.254 \\
\hline Extant species & Giraffa sp. & NHMB-Z-553 & 2.21 & 0.00171 & 0.300 \\
\hline Extant species & Giraffa sp. & SMNS-30171 & 3.06 & 0.00192 & 0.481 \\
\hline Extant species & Giraffa sp. & SNG-35595 & 1.82 & 0.00066 & 0.311 \\
\hline Extant species & Giraffa sp. & SNG-36628 & 1.76 & 0.00126 & 0.298 \\
\hline Extant species & Giraffa sp. & SNG-497 & 2.98 & 0.00043 & 0.350 \\
\hline Extant species & Giraffa sp. & SNG-498 & 1.76 & 0.00415 & 0.279 \\
\hline Extant species & Giraffa sp. & SNG-501 & 6.75 & 0.00149 & 0.606 \\
\hline Extant species & Okapia johnstoni & MRAC-1025 & 3.10 & 0.00226 & 0.474 \\
\hline Extant species & Okapia johnstoni & MRAC-1192 & 3.93 & 0.00461 & 0.381 \\
\hline Extant species & Okapia johnstoni & MRAC-1193 & 4.48 & 0.00174 & 0.371 \\
\hline Extant species & Okapia johnstoni & MRAC-2904 & 1.38 & 0.00608 & 0.433 \\
\hline Extant species & Okapia johnstoni & MRAC-3074 & 3.19 & 0.00427 & 0.483 \\
\hline Extant species & Okapia johnstoni & MRAC-3075 & 2.82 & 0.00151 & 0.375 \\
\hline Extant species & Okapia johnstoni & MRAC-3076 & 2.37 & 0.00454 & 0.260 \\
\hline Extant species & Okapia johnstoni & MRAC-4051 & 1.32 & 0.00762 & 0.636 \\
\hline Extant species & Okapia johnstoni & MRAC-6293 & 1.99 & 0.00246 & 1.302 \\
\hline Extant species & Okapia johnstoni & MRAC-705B & 4.49 & 0.00061 & 0.442 \\
\hline Extant species & Okapia johnstoni & MRAC-8358 & 1.82 & 0.00542 & 0.445 \\
\hline Extant species & Okapia johnstoni & MRAC-8663 & 3.36 & 0.00127 & 0.552 \\
\hline Extant species & Okapia johnstoni & MRAC-9726 & 2.23 & 0.00634 & 0.230 \\
\hline Extant species & Okapia johnstoni & MRAC-9727 & 1.81 & 0.00537 & 0.774 \\
\hline Extant species & Okapia johnstoni & NHMB-Z-1085 & 1.22 & 0.00738 & 0.470 \\
\hline Extant species & Okapia johnstoni & NHMB-Z-243 & 1.69 & 0.00346 & 0.603 \\
\hline Extant species & Okapia johnstoni & NHMB-Z-245 & 0.88 & 0.00311 & 0.533 \\
\hline Extant species & Okapia johnstoni & NHMB-Z-2908 & 0.74 & 0.00472 & 0.208 \\
\hline Extant species & Okapia johnstoni & NHMB-Z-329 & 2.36 & 0.00268 & 1.019 \\
\hline Extant species & Okapia johnstoni & NHMB-Z-576 & 4.42 & 0.00288 & 0.133 \\
\hline Extant species & Okapia johnstoni & NMHB-C3899 & 0.44 & 0.00192 & 0.603 \\
\hline Extant species & Okapia johnstoni & NMHB-C3900 & 0.56 & 0.00279 & 0.533 \\
\hline Extant species & Okapia johnstoni & NHMB-Z-2308 & 1.32 & 0.00749 & 0.276 \\
\hline Extant species & Okapia johnstoni & NHMB-Z-244 & 6.27 & 0.00544 & 0.534 \\
\hline Extant species & Okapia johnstoni & NHMB-Z-3686 & 3.26 & 0.00585 & 0.887 \\
\hline
\end{tabular}




\begin{tabular}{|c|c|c|c|c|c|c|c|}
\hline State & Species & Individual & Asfc & epLsar 1.8 & asfc 9 cells & Region & Site \\
\hline Extinct species & Bohlinia attica & LGPUT-NKT-147-UM2 & 0.91 & 0.00211 & 0.343 & Greece & Nikiti-1 \\
\hline Extinct species & Bohlinia attica & AM-NMNHS-K 5206 & 1.07 & 0.00317 & 0.533 & Bulgaria & Kalimantsi \\
\hline Extinct species & Bohlinia attica & AM-NMNHS-K 5209 & 1.23 & 0.00301 & 0.518 & Bulgaria & Kalimantsi \\
\hline Extinct species & Bohlinia attica & LGPUT-NKT-148-UM2 & 1.44 & 0.00097 & 0.432 & Greece & Nikiti-1 \\
\hline Extinct species & Bohlinia attica & LGPUT-NKT-145-UM2 & 2.72 & 0.00307 & 0.618 & Greece & Nikiti-1 \\
\hline Extinct species & Palaeogiraffa paimiri & MNHN TRQ-430 & 0.66 & 0.00142 & 0.259 & Turkey & Küçükçekmece \\
\hline Extinct species & Palaeogiraffa paimiri & MNHN TRQ-428 & 0.78 & 0.00215 & 0.433 & Turkey & Küçükçekmece \\
\hline Extinct species & Palaeogiraffa paimiri & MNHN TRQ-424 & 1.10 & 0.00103 & 0.317 & Turkey & Küçükçekmece \\
\hline Extinct species & Palaeogiraffa paimiri & MNHN TRQ-422 & 2.36 & 0.00131 & 0.533 & Turkey & Küçükçekmece \\
\hline Extinct species & Palaeogiraffa paimiri & MNHN TRQ-425 & 2.56 & 0.00187 & 0.427 & Turkey & Küçükçekmece \\
\hline Extinct species & Palaeogiraffa paimiri & MNHN TRQ-432 & 2.62 & 0.00372 & 1.068 & Turkey & Küçükçekmece \\
\hline Extinct species & Helladotherium duvernoyi & AM-NMNHS-HD 5157 & 0.88 & 0.00343 & 0.645 & Bulgaria & Hadjidimovo \\
\hline Extinct species & Helladotherium duvernoyi & AM-NMNHS-K 5198 & 1.06 & 0.00290 & 0.207 & Bulgaria & Kalimantsi \\
\hline Extinct species & Helladotherium duvernoyi & MNHN-PIK1501 & 1.08 & 0.00278 & 0.267 & Greece & Pikermi \\
\hline Extinct species & Helladotherium duvernoyi & AM-NMNHS-K 5159 & 1.58 & 0.00146 & 0.490 & Bulgaria & Kalimantsi \\
\hline Extinct species & Helladotherium duvernoyi & AM-NMNHS-HD 5200 & 1.69 & 0.00471 & 0.747 & Bulgaria & Hadjidimovo \\
\hline Extinct species & Helladotherium duvernoyi & FSL16753-M1 & 2.12 & 0.00137 & 0.249 & Algeria & Douaria \\
\hline Extinct species & Helladotherium duvernoyi & AM-NMNHS-K 5161 & 2.23 & 0.00187 & 0.106 & Bulgaria & Kalimantsi \\
\hline Extinct species & Helladotherium duvernoyi & LGPUT-NIK 1804 & 2.27 & 0.00555 & 0.298 & Greece & Nikiti-2 \\
\hline Extinct species & Helladotherium duvernoyi & LGPUT-NIK 1057 & 2.32 & 0.00472 & 0.250 & Greece & Nikiti-2 \\
\hline Extinct species & Helladotherium duvernoyi & LGPUT-NIK 1 & 2.34 & 0.00362 & 0.152 & Greece & Nikiti-2 \\
\hline Extinct species & Helladotherium duvernoyi & AM-NMNHS-K 5156 & 2.50 & 0.00138 & 0.221 & Bulgaria & Kalimantsi \\
\hline Extinct species & Helladotherium duvernoyi & LGPUT-RZO189 & 3.52 & 0.00128 & 0.177 & Greece & Ravin des Zouaves- 5 \\
\hline Extinct species & Helladotherium duvernoyi & AM-NMNHS-HD 5204 & 4.01 & 0.00292 & 0.239 & Bulgaria & Hadjidimovo \\
\hline Extinct species & Helladotherium duvernoyi & AM-NMNHS-K 5197 & 4.55 & 0.00421 & 2.179 & Bulgaria & Kalimantsi \\
\hline Extinct species & Helladotherium duvernoyi & MNHN-MNHN-PIK1500 & 4.77 & 0.00280 & 0.264 & Greece & Pikermi \\
\hline Extinct species & Palaeogiraffa macedoniae & LGPUT-PNT 137 & 2.00 & 0.00150 & 0.329 & Greece & Pentalophos \\
\hline Extinct species & Palaeogiraffa macedoniae & LGPUT-PNT 328 & 2.01 & 0.00682 & 0.357 & Greece & Pentalophos \\
\hline Extinct species & Palaeogiraffa macedoniae & LGPUT-PNT 136 & 2.33 & 0.00669 & 0.194 & Greece & Pentalophos \\
\hline Extinct species & Palaeogiraffa macedoniae & LGPUT-PNT 112 & 2.75 & 0.00346 & 0.488 & Greece & Pentalophos \\
\hline Extinct species & Palaeogiraffa macedoniae & LGPUT-PNT 111A & 2.86 & 0.00376 & 0.220 & Greece & Pentalophos \\
\hline Extinct species & Palaeogiraffa macedoniae & LGPUT-PNT 121 & 3.72 & 0.00851 & 0.545 & Greece & Pentalophos \\
\hline Extinct species & Palaeogiraffa major & LGPUT-RPL 734 & 2.87 & 0.00641 & 0.381 & Greece & Ravin de la Pluie \\
\hline Extinct species & P. coelophrys & MNHN-MAR-669 & 1.30 & 0.00108 & 0.419 & Iran & Maragheh \\
\hline Extinct species & P. coelophrys & LGPUT-RPL104 & 1.32 & 0.00592 & 0.304 & Greece & Ravin de la Pluie \\
\hline Extinct species & P. coelophrys & LGPUT-PNT113 & 2.91 & 0.00379 & 0.287 & Greece & Pentalophos \\
\hline Extinct species & Palaeotragus rouenii & MNHN-MOL-4211 & 0.68 & 0.00400 & 0.341 & Afghanistan & Molayan \\
\hline Extinct species & Palaeotragus rouenii & MNHN-MOL-4201 & 0.78 & 0.00488 & 0.363 & Afghanistan & Molayan \\
\hline Extinct species & Palaeotragus rouenii & LGPUT-DIT-2-UM2-a.sur & 1.15 & 0.00554 & 0.175 & Greece & Dytiko \\
\hline Extinct species & Palaeotragus rouenii & NHML-PIK-M11453\#5 & 1.39 & 0.00131 & 0.284 & Greece & Pikermi \\
\hline Extinct species & Palaeotragus rouenii & LGPUT-RPI-91b-UM2 & 1.40 & 0.00650 & 0.422 & Greece & Ravin de la Pluie \\
\hline Extinct species & Palaeotragus rouenii & NHML-PIK-M11419\#7 & 1.46 & 0.00235 & 0.271 & Greece & Pikermi \\
\hline Extinct species & Palaeotragus rouenii & NHML-PIK-M11419\#3 & 1.78 & 0.00338 & 0.429 & Greece & Pikermi \\
\hline Extinct species & Palaeotragus rouenii & AMNHS-MTLB52 & 1.80 & 0.00483 & 0.232 & Greece & Mytilinii B \\
\hline Extinct species & Palaeotragus rouenii & MTA-MYS351 & 1.81 & 0.00573 & 0.299 & Turkey & Serefköy-2 \\
\hline Extinct species & Palaeotragus rouenii & MNHN-MOL-4212 & 1.93 & 0.00266 & 0.732 & Afghanistan & Molayan \\
\hline Extinct species & Palaeotragus rouenii & LGPUT-DIT-3-UM2 & 2.04 & 0.00342 & 0.221 & Greece & Dytiko \\
\hline Extinct species & Palaeotragus rouenii & MNHN-PIK1671 & 2.19 & 0.00277 & 0.371 & Greece & Pikermi \\
\hline Extinct species & Palaeotragus rouenii & AM-NMNHS-HD 5190 & 2.43 & 0.00228 & 0.372 & Bulgaria & Hadjidimovo \\
\hline Extinct species & Palaeotragus rouenii & NHMEU-PV-1598 & 2.58 & 0.00493 & 0.299 & Turkey & Serefköy-2 \\
\hline Extinct species & Palaeotragus rouenii & NHMEU-PV-1629 & 2.69 & 0.00610 & 0.348 & Turkey & Serefköy-2 \\
\hline Extinct species & Palaeotragus rouenii & MNHN-PIK1672 & 2.99 & 0.00464 & 0.388 & Greece & Pikermi \\
\hline Extinct species & Palaeotragus rouenii & AMNHS-MTLB128 & 3.53 & 0.00457 & 0.378 & Greece & Mytilinii B \\
\hline Extinct species & Palaeotragus rouenii & NHML-PIK M11419\#9 & 3.66 & 0.00493 & 0.298 & Greece & Pikermi \\
\hline Extinct species & Palaeotragus rouenii & MTA-MYS-299 & 3.75 & 0.00144 & 0.457 & Turkey & Serefköy-1 \\
\hline Extinct species & Palaeotragus rouenii & MNHN-PIK1674 & 3.77 & 0.00225 & 0.366 & Greece & Pikermi \\
\hline Extinct species & Palaeotragus rouenii & NHML-PIKM11419\#4 & 4.40 & 0.00129 & 0.282 & Greece & Pikermi \\
\hline Extinct species & Samotherium boissieri & NHMB-Sam29 & 0.76 & 0.00651 & 0.408 & Greece & Samos \\
\hline Extinct species & Samotherium boissieri & NHML-Samos-M-4226 & 1.39 & 0.00658 & 0.179 & Greece & Samos \\
\hline Extinct species & Samotherium boissieri & NHML-Samos-M-4235 & 2.67 & 0.00418 & 0.418 & Greece & Samos \\
\hline Extinct species & Samotherium boissieri & NHML-Samos-M4234d-No14 & 3.41 & 0.00163 & 0.559 & Greece & Samos \\
\hline Extinct species & Samotherium boissieri & NHML-Samos-M-4241 & 3.93 & 0.00596 & 0.302 & Greece & Samos \\
\hline Extinct species & Samotherium major & LGPUT-VAT-157-Im2 & 1.41 & 0.00481 & 0.178 & Greece & Vathylakkos \\
\hline Extinct species & Samotherium major & AMNHS-MTLA- 540 & 1.59 & 0.00530 & 0.429 & Greece & Mytilinii A \\
\hline Extinct species & Samotherium major & AMNHS-MTLA-311 & 1.79 & 0.00545 & 0.228 & Greece & Mytilinii A \\
\hline Extinct species & Samotherium major & MTA-MYS-843 & 2.25 & 0.00441 & 0.279 & Turkey & Salihpasalar \\
\hline Extinct species & Samotherium major & AMNHS-MTLB95 & 2.71 & 0.00479 & 0.336 & Greece & Mytilinii B \\
\hline Extinct species & Samotherium major & MTA-MYS-848 & 4.63 & 0.00089 & 0.562 & Turkey & Salihpasalar \\
\hline Extinct species & Samotherium major & MTA-MYS-620 & 4.95 & 0.00238 & 0.939 & Turkey & Serefköy-1 \\
\hline Extinct species & Samotherium major & MTA-MYS-847 & 5.21 & 0.00198 & 0.159 & Turkey & Salihpasalar \\
\hline Extinct species & Samotherium major & SMNK-MA3 & 1.16 & 0.00325 & 0.254 & Turkey & Mahmut Ghazi \\
\hline Extinct species & Samotherium neumayeri & MNHN-MAR-528 & 0.66 & 0.00199 & 0.149 & Iran & Maragheh \\
\hline
\end{tabular}

